\title{
Hippocampal Telomerase Is Involved in the Modulation of Depressive Behaviors
}

\author{
Qi-Gang Zhou, ${ }^{1 \star}$ Yao Hu, ${ }^{1 \star}$ Dan-Lian Wu, ${ }^{1}$ Li-Juan Zhu, ${ }^{1}$ Chen Chen, ${ }^{1}$ Xing Jin, ${ }^{1}$ Chun-Xia Luo, ${ }^{1,2}$ Hai-Yin Wu, ${ }^{2}$ \\ Jing Zhang, ${ }^{1}$ and Dong-Ya Zhu ${ }^{1,2}$ \\ ${ }^{1}$ Department of Pharmacology, School of Pharmacy, and 2Laboratory of Cerebrovascular Disease, Nanjing Medical University, Nanjing 210029, China
}

Telomere and telomerase alterations have been reported in mood disorders. However, the role of telomerase in depression remains unclear. Here we show that chronic mild stress (CMS) led to a significant decrease in telomerase reverse transcriptase (TERT) level and telomerase activity in the hippocampus. Treatment with antidepressant fluoxetine reversed the CMS-induced TERT and telomerase activity changes. Inhibiting telomerase by systemic administration $\left(100 \mathrm{mg} \cdot \mathrm{kg}^{-1} \cdot \mathrm{d}^{-1}\right.$, i.p., for $\left.14 \mathrm{~d}\right)$, intrahippocampal microinjection $(0.7 \mu \mathrm{mol}, 2 \mu \mathrm{l})$, or infusion (using an osmotic minipump, $0.134 \mu \mathrm{g} / \mu \mathrm{l}, 0.25 \mu \mathrm{l} / \mathrm{h}$ ) of $3^{\prime}$-azido-deoxythymidine (AZT) resulted in depression-like behaviors and impaired hippocampal neurogenesis in mice. In contrast, overexpressing telomerase by intrahippocampal infusion of recombinant adenovirus vector expressing mouse TERT (Ad-mTERT-GFP) led to neurogenesis upregulation, produced antidepressant-like behaviors, and prevented the CMS-induced behavioral modifications. Disrupting neurogenesis in the dentate gyrus by X-irradiation ( $15 \mathrm{~Gy}$ ) of a restricted region of mouse brain containing the hippocampus abolished the antidepressant-like effect of Ad-mTERT-GFP. Additionally, AZT had no effect on DNA polymerase activity and did not cause cell damage in vitro and in vivo. Microinjection of AZT into the subventricular zone of lateral ventricle $(0.7 \mu \mathrm{mol}, 2 \mu \mathrm{l})$ inhibited local neurogenesis but had no behavioral effect. These results suggest that hippocampal telomerase is involved in the modulation of depression-related behaviors, possibly by regulating adult neurogenesis.

\section{Introduction}

The hippocampus is one of several limbic brain structures implicated in the pathophysiology and treatment of mood disorders (Warner-Schmidt and Duman, 2006). Several lines of evidence suggest implications of adult hippocampal neurogenesis in antidepressant action (Santarelli et al., 2003; Kodama et al., 2004; Malberg, 2004; Dranovsky and Hen, 2006; Airan et al., 2007; Perera et al., 2007; Sahay and Hen, 2007). Stress, which triggers bouts of depression (Tsankova et al., 2006), suppresses adult hippocampal neurogenesis (Jacobs et al., 2000; Czeh et al., 2001), and antidepressant drugs counteract this effect (Czeh et al., 2001). Moreover, irradiation of the hippocampus, which reduces hippocampal neurogenesis, abolishes the behavioral and prolif-

\footnotetext{
Received Feb. 14, 2011; revised June 28, 2011; accepted July 1, 2011.

Author contributions: D.-Y.Z. designed research; Q.-G.Z., Y.H., D.-L.W., L.-J.Z., C.C., X.J., C.-X.L., H.-Y.W., and J.Z. performed research; H.-Y.W. contributed unpublished reagents/analytic tools; Q.-G.Z. and Y.H. analyzed data; D.Y.Z. wrote the paper.

This work was supported by grants from the National Basic Research Program of China (973 Program; 2011CB504400 to D.-Y.Z.), National Natural Science Foundation of China (30870900, 30971021, and 81030023 to D.-Y.Z.; 81000586 to Q.-G.Z.), Natural Science Foundation of Jiangsu Province (BK2007728 to D.-Y.Z.), Specialized Research Fund for the Doctoral Program of Higher Education (200803120008 to D.-Y.Z.), and Science and Technology Foundation of Nanjing Medical University (09NJMUZ15 to Q.-G.Z.). We thank W. X. Sun and H. B. Xu for technical assistance.

${ }^{*} Q$.-G.Z. and Y.H. contributed equally to this work.

Correspondence should be addressed to Prof. Dong-Ya Zhu, Department of Pharmacology, School of Pharmacy, Laboratory of Cerebrovascular Disease, Nanjing Medical University, Nanjing 210029, China. E-mail: dyzhu@ njmu.edu.cn.

DOI:10.1523/JNEUROSCI.0805-11.2011

Copyright $\odot 2011$ the authors $\quad 0270-6474 / 11 / 3112258-12 \$ 15.00 / 0$
}

erative effects of many different antidepressants (Santarelli et al., 2003; Airan et al., 2007).

Telomere length is essential for the prolonged persistence of stem cell function in organs with extensive cell turnover (Flores et al., 2006, 2008). In proliferative cells, telomere length is maintained by telomerase, a DNA polymerase that consists of an RNA component (TERC) and a catalytic subunit, telomerase reverse transcriptase (TERT), and adds six-base DNA repeats (TTAGGG) onto the telomeric ends of chromosomes (Feng et al., 1995; Blackburn, 2001). Telomerase is present at high levels in neural progenitor cells in the developing (Klapper et al., 2001; Cai et al., 2002) and adult (Caporaso et al., 2003) brain. Recently, telomere dysfunction in peripheral leukocytes has been described in psychiatric conditions. Accelerated telomere shortening and decreased telomerase activity has been reported in chronically stressed individuals (Epel et al., 2004), mood disorders (Simon et al., 2006), and schizophrenia (Kao et al., 2008; Porton et al., 2008). Moreover, mouse TERT (mTERT)-deficient mice exhibited significantly altered anxiety-like behaviors (Lee et al., 2010). Thus, telomerase may be involved in the procedure of adult neurogenesis and the regulation of mood behaviors. Here we investigated the effects of telomerase inhibition or overexpression on depression-related behaviors and hippocampal neurogenesis and reported that hippocampal telomerase plays a role in the modulation of depression-related behaviors via regulating adult neurogenesis.

\section{Materials and Methods}

Mice

C57BL/6 mice (Model Animal Research Center of Nanjing University), weighing 18-22 g, were used for the experimental procedures. Mice were allowed 1 week to acclimate before experimentation. Animals were 
housed in plastic cages with bedding. Food and tap water were available ad libitum for the duration of the experiments unless otherwise noted. The temperature was maintained at $22 \pm 2^{\circ} \mathrm{C}$. A $12 \mathrm{~h}$ light/dark cycle was maintained, with lights on at 6:00 A.M. The experimental protocol was approved by the Institutional Animal Care and Use Committee of Nanjing Medical University.

\section{Drugs}

5-Bromo-2'-deoxyuridine (BrdU) and Azidothymidine [3'-azido-3'deoxythymidine (AZT)] were purchased from Sigma-Aldrich.

\section{Chronic mild stress and behavioral measures}

The procedure of chronic mild stress (CMS) was designed as described previously (Ducottet et al., 2003). In brief, the CMS protocol consists of the sequential application of a variety of mild stressors, including restraint, forced swimming, water and/or food deprivation, and pairing with another stressed animal in wet sawdust, housing in wet sawdust, reversal of the light/dark cycle, and housing in constant illumination or darkness each for a period ranging from $10 \mathrm{~min}$ to $24 \mathrm{~h}$, in a schedule that lasts for 3 weeks. The schedule is repeated thereafter from week 1 .

Tail suspension test. Mice were moved from the housing room to the testing area in their home cages and allowed to adapt to the new environment for at least $1 \mathrm{~h}$ before testing. Mice were suspended by their tail with adhesive tape to a hook in a soundproof box. The total duration of immobility during a 6 min test was calculated.

Forced swimming test. Mice were individually forced to swim in an open glass cylinder (diameter, $28 \mathrm{~cm}$; height, $33 \mathrm{~cm}$ ) that was filled with water at $25 \pm 1{ }^{\circ} \mathrm{C}$ to a depth of $20 \mathrm{~cm}$. The total duration of immobility during a 6 min test was scored. Each mouse was judged to be immobile when it ceased struggling and remained floating motionless in the water, making only those movements necessary to keep its head above water. Water was replaced between every trial. After swim sessions, mice were removed from the cylinder, dried with a towel, and placed underneath a heating lamp for $\sim 30 \mathrm{~min}$ before being returned to their home cages.

Sucrose preference test. The sucrose preference test (SPT) was performed as described previously (Grippo et al., 2005). In brief, an SPT consisted of first removing the food and water from each mouse's cage for a period of $20 \mathrm{~h}$. Water and $1 \%$ sucrose were then placed on the cages in preweighed plastic bottles, and animals were allowed to consume the fluids for a period of $10 \mathrm{~h}$. The bottles were then removed and weighed. Fluid intake was calculated as a preference score (percentage sucrose preference, relative to total fluid intake).

Open field test. The test arena was constructed of a plastic plate $(56.13 \times 56.13 \mathrm{~cm})$ and divided into 256 squares. It was surrounded by a 35.18 -cm-high plastic wall. Each mouse was placed onto a corner square of the arena, facing the corner, and was allowed to freely explore the open field for 5 min per trial. The number of squares crossed with all paws (crossing) was counted in a 5 min session as horizontal activity, and the number of rearing (stood on its hind legs with the forepaws free) and leaning (stood on its hind legs with one or two forepaws against the wall) positions was noted in a 5 min session as vertical activity. After each trial, the plate was cleaned with $70 \% \mathrm{EtOH}$.

\section{Cell cultures}

Adult NSCs were isolated and cultured as described previously (Luo et al., 2010], with some modifications. In brief, the dentate gyri of 2-monthold female mice ( 10 mice were used in each primary isolation experiment) were dissected and digested with $0.125 \%$ trypsin (Invitrogen) and $250 \mathrm{U} / \mathrm{ml}$ DNase I (Sigma-Aldrich) at $37^{\circ} \mathrm{C}$ for $20 \mathrm{~min}$, and undifferentiated progenitors were enriched by centrifugation with Percoll (GE Healthcare Bio-Sciences). Cells were floating cultured in proliferation medium containing $20 \mathrm{ng} / \mathrm{ml}$ basic fibroblast growth factor (SigmaAldrich), $20 \mathrm{ng} / \mathrm{ml}$ epidermal growth factor (Sigma-Aldrich), and 2\% B27 supplement (Grand Island) and passaged every 4-6 d. Adult NSCs of the second to fourth passage were used in this study.

Primary hippocampal neurons were isolated from an embryonic day 18 mouse and cultured in neurobasal medium (Invitrogen) containing 2\% B27 supplement as reported (Luo et al., 2010). Cultured neurons were identified at $10 \mathrm{~d}$ in vitro, and the proportion of $\beta$-III-tubulin ${ }^{+}$cells was about $92 \%$.

\section{Adenovirus production and infection in vivo}

The coding sequence of mTERT was amplified by RT-PCR. The primer sequences were as follows: forward, 5'-GTAGAACGCAGATCGAATTCATGACCCGCGCTCCTCG-3'; reverse, 5'-CCCTTGCTCACCATGAATTCGTCCAAAATGGTCTGAAAGTC- $3^{\prime}$. The PCR fragments and the pDC315-GFP plasmid were digested with EcoR I and ligated with T4 DNA ligase to produce pDC315-mTERT-GFP. The plasmid was used to transform competent $\mathrm{DH} 5 \alpha$ Escherichia coli bacterial strains for identification. Using $10 \mu \mathrm{l}$ of Lipofectamine 2000 mixed with $50 \mu \mathrm{l}$ of DMEM, HEK293 cells were cotransfected with $5 \mu \mathrm{g}$ of the pDC315-GFP plasmid with a cDNA encoding mTERT and $5 \mu \mathrm{g}$ of the pBHG lox $\Delta \mathrm{E} 1,3$ Cre plasmid as a helper plasmid to generate the recombinant adenovirus, Ad-mTERT-GFP. After $8 \mathrm{~d}$, supernatant was harvested from HEK293 cells. After 3 times the virus amplification, the supernatant was filtered at $0.45 \mu \mathrm{m}$ and purified using the Adeno-X Virus Purification kit. After resuspension, serially diluted adenovirus was used to transduce HEK293 cells. Seven days later, labeled HEK293 cells were counted to calculate the viral titer $\left(\sim 2.5 \times 10^{10} \mathrm{pfu} / \mathrm{ml}\right)$.

Ad-mTERT-GFP and Ad-GFP (control) were transfected into mouse hippocampus by stereotaxic microinjection at $1 \mu \mathrm{l}$ per dentate gyrus (DG). Five days later, mice were perfused transcardially, and serial brain sections $(40 \mu \mathrm{m})$ were made. Effects of transfection in vivo could be observed by fluorescence microscope.

\section{Microinjection and infusion of $A Z T$}

Adult mice were anesthetized with $0.07 \mathrm{ml}$ of a mixture of ketamine $(90.9$ $\mathrm{mg} / \mathrm{ml})$ and xylazine $(9.1 \mathrm{mg} / \mathrm{ml})$ and placed in a stereotaxic apparatus. AZT was dissolved in a solution (physiological saline/polyethylene glycol $400,4: 1)$. The AZT solution in $2 \mu \mathrm{l}$ volume was microinjected into the DG $(0.2 \mu \mathrm{l} / \mathrm{min})$ at coordinates $2.3 \mathrm{~mm}$ posterior to bregma, $1.3 \mathrm{~mm}$ lateral to the midline, and $2.0 \mathrm{~mm}$ below dura (Munoz et al., 2005), or into the subventricular zone (SVZ) of the anterior part of the lateral ventricle $(0.2 \mu \mathrm{l} / \mathrm{min})$ at coordinates $1 \mathrm{~mm}$ anterior to bregma, $1 \mathrm{~mm}$ lateral to the midline, and $2.3 \mathrm{~mm}$ below dura (Yoon et al., 1996). For the osmotic pump infusion, a 7 or $28 \mathrm{~d}$ Alzet osmotic minipump containing AZT $(6.7 \mu \mathrm{g} / 50 \mu \mathrm{l}$ for $7 \mathrm{~d}$ or $26.8 \mu \mathrm{g} / 200 \mu \mathrm{l}$ for $28 \mathrm{~d}$ ) was placed subcutaneously in the back of the animals, and a brain infusion cannula connected to the pump was positioned at the following coordinates: $2.3 \mathrm{~mm}$ posterior to bregma, $1.3 \mathrm{~mm}$ lateral to the midline, and $2.0 \mathrm{~mm}$ below dura (Munoz et al., 2005). The infusion rate was $0.25 \mu \mathrm{l} / \mathrm{h}$. We anesthetized mice with a mixture of ketamine $(90.9 \mathrm{mg} / \mathrm{ml})$ and xylazine $(9.1$ $\mathrm{mg} / \mathrm{ml}$ ) and removed the osmotic pump after infusing AZT solution for 7 or $28 \mathrm{~d}$.

\section{Hippocampal X-irradiation}

$\mathrm{X}$-irradiation was performed according to a modified version of a procedure reported previously (Santarelli et al., 2003). Briefly, mice were anesthetized with $0.07 \mathrm{ml}$ of a mixture of ketamine $(90.9 \mathrm{mg} / \mathrm{ml})$ and xylazine $(9.1 \mathrm{mg} / \mathrm{ml})$, placed in a stereotaxic apparatus, and exposed to cranial irradiation using therapeutical $\mathrm{x}$-ray equipment operated at $300 \mathrm{kVp}$ and $20 \mathrm{~mA}$. Mice were protected with a lead shield that covered the entire body, with the exception of a $3.2 \times 11 \mathrm{~mm}$ treatment field above the hippocampus. The corrected dose rate was $\sim 3 \mathrm{~Gy} / \mathrm{min}$ at a source-toskin distance of $100 \mathrm{~cm}$. The procedure lasted $1 \mathrm{~min}$ and $42 \mathrm{~s}$, delivering a total of 5 Gy each time.

Experiment 1. For the $10 \mathrm{~Gy}$ dose group, two $5 \mathrm{~Gy}$ doses were delivered to the hippocampus of mice on days 0 and 4, respectively. For the $15 \mathrm{~Gy}$ dose group, three 5 Gy doses were delivered on days 0 , 4, and 8, respectively. To assess the effects of this procedure on the survival of newly born cells, mice were given injections of BrdU (four times, $50 \mathrm{mg} / \mathrm{kg}$, i.p., at $6 \mathrm{~h}$ intervals) on day 12. Behavioral tests were performed on day 36 , and animals were killed on day 40 for BrdU staining.

Experiment 2. Three 5 Gy doses were delivered on days 6, 10, and 14 after Ad-mTERT-GFP intrahippocampal infusion, respectively. To assess the effects of this procedure on newborn cell survival, mice were given injections of $\mathrm{BrdU}$ (four times, $50 \mathrm{mg} / \mathrm{kg}$, i.p., at $6 \mathrm{~h}$ intervals) on day 18. Behavioral tests were performed on day 34 . Animals were killed on day 46, and brain slices were prepared for BrdU staining. 
Immunocytochemistry and cell counting The mice were anesthetized with chloral hydrate $\left(30 \mathrm{mg} \mathrm{kg}^{-1}\right.$, i.p.) and perfused transcardially with saline followed by $4 \%$ paraformaldehyde. Brains were removed and postfixed overnight in the same solution. Serial sections $(40 \mu \mathrm{m})$ were made on an oscillating tissue slicer in a bath of physiological saline. Every fifth section throughout the hippocampus or SVZ was processed for BrdU immunohistochemistry as described previously (Zhu et al., 2003). All BrdUlabeled cells in the DG or SVZ were counted in each section by another experimenter blinded to the study code. The total number of BrdU-labeled cells per section was determined.

\section{Fluoro-Jade and terminal}

deoxynucleotidyl transferase-mediated dUTP nick-end labeling staining

Neuronal degeneration was determined by Fluoro-Jade (FJ; Histo-Chem) staining. In brief, sections were washed and mounted on glass slides and dried overnight. The slides were immersed for $3 \mathrm{~min}$ in absolute ethanol, for 1 min in $70 \%$ ethanol, and for $1 \mathrm{~min}$ in distilled water and transferred to a solution containing $0.01 \%$ Fluoro-Jade and $0.1 \%$ acetic acid for 30 min on a shaker. After three $10 \mathrm{~min}$ washes, the slides were finally coverslipped, and we used the terminal deoxynucleotidyl transferasemediated dUTP nick-end labeling (TUNEL) method to identify cell apoptosis (Schwob et al., 2008).

\section{$R T-P C R$}

Total RNA was extracted from the hippocampus using Trizol reagent according to the manufacturer's instructions (Invitrogen). The primers for mTERT and $\beta$-actin were as follows: mTERT: forward, 5'-ATGGCGTTCCTGAGTATG-3'; reverse, 5'-TTCAACCGCAAGACCGACAG-3'; $\beta$-actin: forward, $5^{\prime}$-CACGATGGAGGGGCCGGACTCATC-3'; reverse, 5' ${ }^{\prime}$-TAAAGACCTCTATGCCAACACAGT-3'. PCR conditions were 30 cycles of denaturation at $94^{\circ} \mathrm{C}$ for $45 \mathrm{~s}$, annealing at $65^{\circ} \mathrm{C}$ for $45 \mathrm{~s}$, and extension at $72^{\circ} \mathrm{C}$ for $45 \mathrm{~s}$. PCR products were separated by electrophoresis through a $1.5 \%$ agarose gel containing $0.5 \% \mu \mathrm{g} / \mathrm{ml}$ ethidium bromide and imaged using a BioDoc-IT imaging system (Bio-Rad).

\section{Western blotting analysis}

Samples from hippocampal tissues of mice were prepared as described in our previous studies (Luo et al., 2010). The samples containing equivalent amounts of protein $(10 \mu \mathrm{g})$ were applied to $8 \%$ acrylamide denaturing gels (SDS-PAGE). The separated proteins were transferred onto nitrocellulose membranes overnight at $4^{\circ} \mathrm{C}$. Blotting membranes were incubated with blocking solution [5\% nonfat dried milk powder dissolved in TBST buffer ( $\mathrm{pH} 7.5,10 \mathrm{~mm}$ Tris- $\mathrm{HCl}, 150 \mathrm{~mm} \mathrm{NaCl}$, and $0.1 \%$ Tween 20)] for $1 \mathrm{~h}$ at room temperature, washed three times, and incubated with rabbit anti-mTERT (1:2000; Santa Cruz Biotechnology) in TBST overnight at $4^{\circ} \mathrm{C}$. Internal control was performed using $\beta$-actin antibody (1:1000; Sigma-Aldrich). After several washes with TBST buffer, the membranes were incubated for $1 \mathrm{~h}$ with a horseradish peroxidaselinked secondary antibody $(1: 10,000)$. The membranes were then processed with enhanced chemiluminescence Western blotting detection reagents (Pierce). The films were scanned, and densitometry was performed using the Quantity One image software (Bio-Rad). The relative level of the protein was quantified from the scanned films.
B

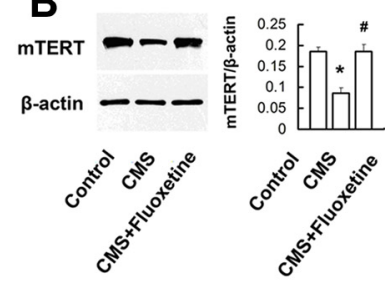

$E$
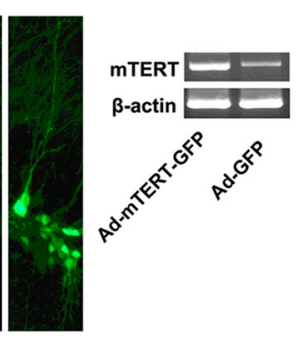

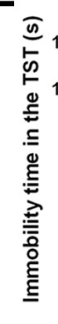

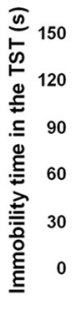

DAdGP Ad-mTERT-GFP

H

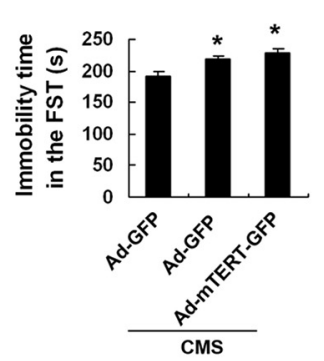

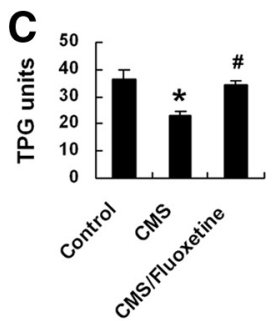

$\mathbf{F}$
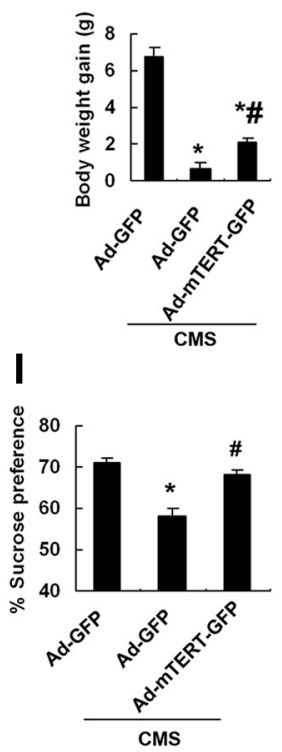

Figure 1. Implication of hippocampal telomerase alterations in depressive behaviors. $\boldsymbol{A}$, Representative SYBR Green I-stained gel visualizing telomerase activity by TRAP products in the hippocampus of mice exposed to CMS for $21 \mathrm{~d}$. Negative control 1, Taq enzyme-free control; Negative control 2, cell-free control; Positive control, cell line expressing a high level of telomerase; HeatImmunoblots showing protein level of TERT in the hippocampus of mice $(n=3)$. C, Telomerase activity in the hippocampus of mice $(n=3)$. In $\boldsymbol{B}$ and $\boldsymbol{C}$, the mice were exposed to CMS for $49 \mathrm{~d}$ and treated with fluoxetine or vehicle during the last $28 \mathrm{~d}$ of CMS. D, Left, Representative DG area with Ad-mTERT-GFP transfection. Middle, Higher magnification of the boxed area. Right, RT-PCR analysis Ad-GFP at 3 or 28 d after intrahippocampal microinjection $(n=10-12)$. $F-I$, Effects of intrahippocampal Ad-mTERT-GFP trans fection on CMS-induced behavioral modifications. Ad-mTERT-GFP or Ad-GFP was delivered into the bilateral DG of mice by micro, exposed to CMS for $21 \mathrm{~d}$, and their body weight gain $(\boldsymbol{F})$, immobility time in the TST (G) and FS $(\boldsymbol{H})$, and sucrose preference $(\boldsymbol{I})$ were examined on the next day $(n=13-16)$. Data are mean \pm SEM. ${ }^{*} p<0.05$, compared with control $(\boldsymbol{A}-\boldsymbol{C})$ or with Ad-GFP $(\boldsymbol{E}-\boldsymbol{I})$; ${ }^{\#} p<0.05$, compared with CMS $(\boldsymbol{B}, \boldsymbol{C})$ or with $\mathrm{Ad}-\mathrm{GFP} / \mathrm{CMS}(\boldsymbol{F}-\boldsymbol{I})$.

\section{Telomerase activity assay}

Telomeric repeat amplification protocol (TRAP) reactions were performed using the TRAPEZE XL telomerase detection kit (Millipore), following the manufacturer's instructions. The telomerase activity was detected with TRAP (Kim et al., 1994) with some modifications. The fluorescence energy transfer primers were used to generate fluorescently labeled TRAP products, which were quantitatively measured with a fluorescence plate reader (SpectraMax M2e) or visualized after terminal deoxynucleotidyl transferase-mediated dUTP nick-end labeling on a $10 \%$ nondenaturing gel and SYBR Green I (Invitrogen) staining.

\section{DNA polymerase activity assay}

DNA polymerase activities were measured as described previously (Tang et al. 2003) with some modifications. We synthesized three short oligonucleotides: N1, template, 5' -CTGAGGAGAAGTCTGCCGTTACTGCCCTGTGGGGCTAGGTGAA-3'; N2, primer matched to template, $5^{\prime}$-AGTTCACCTA-3'; N3, primer with one base mismatched to template at $3^{\prime}$ end, $5^{\prime}$-AGTTCACCTT- $3^{\prime}$. The hippocampus was homogenized in ice-cold saline and centrifuged at $12,000 \times g$ for $10 \mathrm{~min}$ at $4^{\circ} \mathrm{C}$. The supernatants were collected, and the protein concentration was measured. A solution $(199 \mu \mathrm{l})$ containing $50 \mathrm{mmol} / \mathrm{l}$ Tris- $\mathrm{HCl}, \mathrm{pH}$ 8.0, 5 $\mathrm{nmol} / 1 \mathrm{MgCl}_{2}, 1 \mathrm{mmol} / \mathrm{l}$ DTT, $50 \mu \mathrm{mol} / \mathrm{l} \mathrm{dNTP}$ mixture, $1 \times$ SYBR I, 100 
A
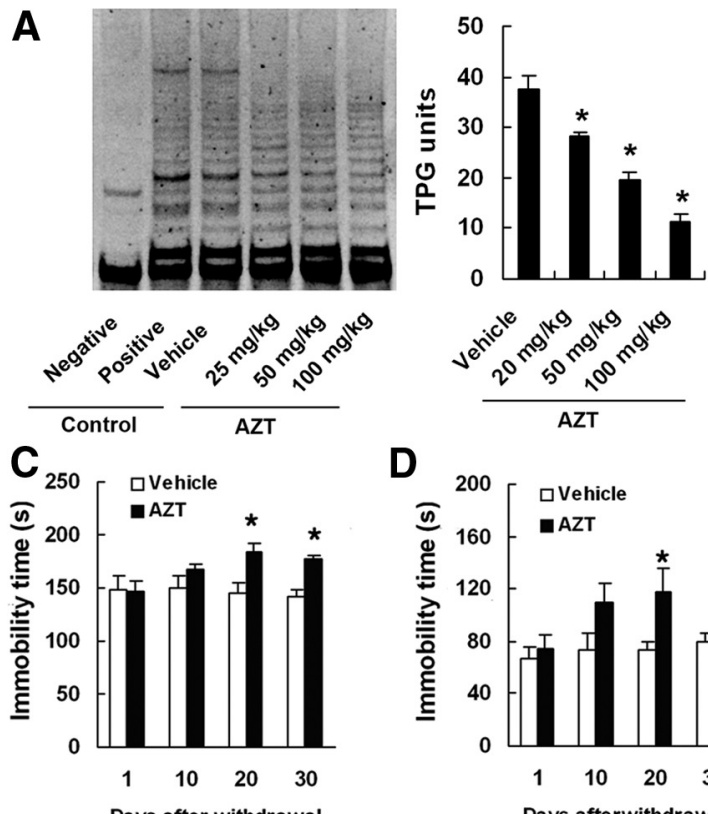

Days after withdrawal

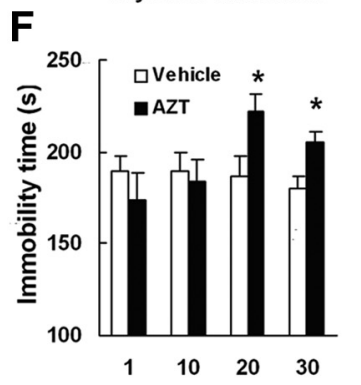

Days after treatment
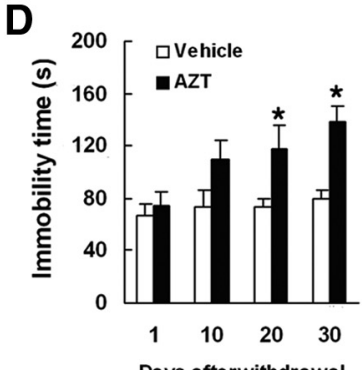

G

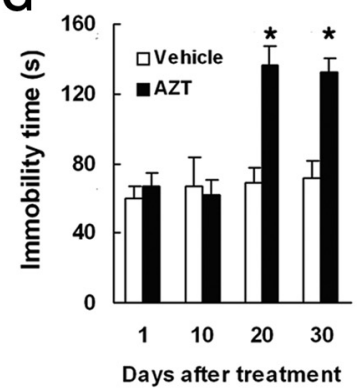

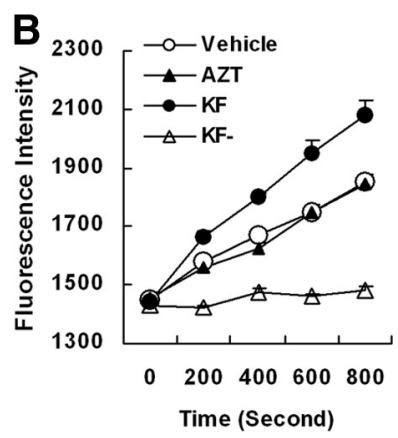

E

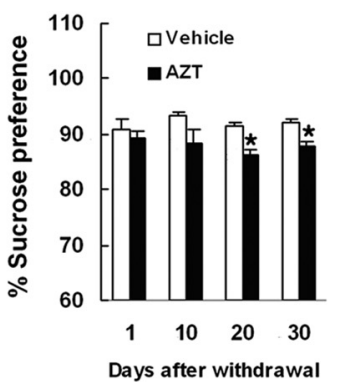

H

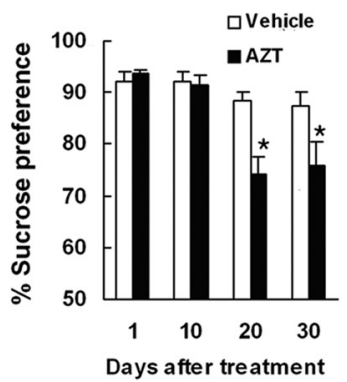

Figure 2. AZT inhibits telomerase activity and produces depressive-like phenotype. $A$, Representative SYBR Green I-stained gel visualizing TRAP products (left) and telomerase activity (right) in the hippocampus of mice treated with 25,50 , or $100 \mathrm{mg} / \mathrm{kg}$ AZT for $7 \mathrm{~d}(n=3)$. Negative control, Taq enzyme-free control; positive control, cell line expressing high levels of telomerase. $\boldsymbol{B}$, Time scan of fluorescence intensity of samples showing DNA polymerase activity in the hippocampus of mice treated with $100 \mathrm{mg} / \mathrm{kg}$ AZT or vehicle for $7 \mathrm{~d}(n=3)$. KF, Klenow fragment (DNA polymerase I), a positive control; KF-, without KF, a negative control. $\boldsymbol{C}-\boldsymbol{H}$, Effects of AZT on behavioral phenotype. Shown are the immobility time in the TST $(\boldsymbol{C})$ and FST $(\boldsymbol{D})$ and percentage sucrose preference $(\boldsymbol{E})$ of the mice treated with AZT (100 $\mathrm{mg} / \mathrm{kg}$, i.p.) for $14 \mathrm{~d}$ at the time indicated after withdrawal $(n=10)$ and the immobility time in the TST $(\boldsymbol{F})$ and FST $(\boldsymbol{G})$ and percentage sucrose preference $(\boldsymbol{H})$ of the mice treated with intrahippocampal AZT microinjection $(0.7 \mu \mathrm{mol}, 2 \mu \mathrm{l})$ at the time indicated after microinjections $(n=9-11)$. Data are mean \pm SEM. ${ }^{*} p<0.05$, compared with vehicle.

$\mathrm{nmol} / \mathrm{l} \mathrm{N} 1$, and $100 \mathrm{nmol} / \mathrm{l} \mathrm{N} 2$ (for the negative control, $100 \mathrm{nmol} / \mathrm{l} \mathrm{N} 3$ ) was put in the spectraMax M2e system for monitoring the fluorescent signal at $520 \mathrm{~nm}$ (excited at $497 \mathrm{~nm}$ ). After the value of fluorescent signal was stabilized, $1 \mu \mathrm{l}$ of supernatant or DNA polymerase I [Klenow fragment (KF), positive control] was added into the solution. Then, fluorescence measurements were performed immediately ( $0 \mathrm{~s})$ and at 200, 400s 600 , and 800 s, respectively.

\section{Cell viability of neurons and NSCs}

Cell injury was assessed by staining with a membrane-impermeable DNA-binding dye, propidium iodide (PI; Invitrogen), and counterstaining with Hoechst 33258 . More specifically, after incubation with neurobasal medium containing PI $(1 \mu \mathrm{g} / \mathrm{ml})$ for $15 \mathrm{~min}$, cells were washed three times with PBS and fixed with $4 \%$ paraformaldehyde (in PBS) for $20 \mathrm{~min}$ at room temperature. Cells were then permeabilized with $0.2 \%$ Triton X-100 (in PBS) for 5 min on ice and washed twice with PBS containing Hoechst $33258(10 \mu \mathrm{g} / \mathrm{ml})$. For the NSCs, cells were then incubated with mouse anti-nestin (1:100; Sigma-Aldrich) at $4^{\circ} \mathrm{C}$ overnight. Subsequently, under fluorescent microscopy, red (PI), blue (Hoechst 33258), and green (nestin) fluorescent images were captured to determine the number of injured cells and the total number of cells, respectively. Five different visual fields per culture dish were evaluated.

\section{Cell apoptosis analysis with PI staining by} flow cytometry

To evaluate the extent of apoptotic and necrotic cells, a live-cell suspension was prepared from the hippocampus of mice using $0.1 \%$ papain as described previously (Jhaveri et al., 2010). Cells were harvested and fixed with $70 \%$ prechilled ethanol for at least $12 \mathrm{~h}$ at $-20^{\circ} \mathrm{C}$. After washing twice with PBS, $25 \mu \mathrm{l}$ of $1 \mathrm{mg} / \mathrm{ml}$ Rnase was added and incubated for $30 \mathrm{~min}$ at $37^{\circ} \mathrm{C}$. The cells were stained with $25 \mu \mathrm{l}$ of 1 $\mathrm{mg} / \mathrm{ml} \mathrm{PI}$ in the dark for $30 \mathrm{~min}$ at $37^{\circ} \mathrm{C}$. The DNA content was analyzed by flow cytometry (Becton Dickinson) using a laser with $488 \mathrm{~nm}$ excitation and $560 \mathrm{~nm}$ emission. The peak of hypodiploid DNA below G1 was regarded as the apoptosic peak. Proliferation (percentage) was expressed as $(\% \mathrm{~S}+\% \mathrm{G} 2) /(\% \mathrm{~S}+\% \mathrm{G} 1+$ $\% \mathrm{G} 2)$.

\section{Statistical analyses}

Comparisons among multiple groups were made with one-way ANOVA followed by Scheffe's post hoc test. Comparisons between two groups were made with the two-tailed Student's $t$ test. Data were presented as mean \pm SEM; $p<0.05$ was considered statistically significant.

\section{Results}

Implication of hippocampal telomerase alterations in depressive behaviors CMS has been proposed as a classical chronic stress model of depression (Willner, 1997). Accordingly, we investigated whether CMS exposure changes telomerase expression and activity. CMS exposure for $21 \mathrm{~d}$ led to a significant decrease in telomerase activity in the hippocampus [19.71 \pm 1.47 vs $33.01 \pm 8.32$ total product generated (TPG) units; $n=3-4 ; p=0.0288$ ] (Fig. $1 A)$, suggesting a correlation of chronic stress with telomerase. To examine whether antidepressant affects the CMSinduced telomerase change, we treated mice with fluoxetine (10 $\mathrm{mg} \cdot \mathrm{kg}^{-1} \cdot \mathrm{d}^{-1}$, i.p.), a selective serotonin reuptake inhibitor, from day 22 to day 49 during 49 d CMS exposure and measured TERT level and telomerase activity in the hippocampus and immobility time in the tail suspension test (TST). Mice exposed to CMS for $49 \mathrm{~d}$ displayed a significantly decreased TERT protein level $\left(F_{(2,6)}=54.17 ; p=0.000\right)$ (Fig. $1 B$ ) and telomerase activities $\left(F_{(2,9)}=9.27 ; p=0.009\right)$ (Fig. $1 C$ ) and prolonged latency in the TST $(151.2 \pm 8.3$ vs $82.0 \pm 4.6 \mathrm{~s}$, CMS vs control; $\left.F_{(2,30)}=18.83 ; p=0.000 ; n=9-12\right)$. Fluoxetine treatments reversed the CMS-induced TERT $\left(F_{(2,6)}=54.17 ; p=0.01\right)$ (Fig. $1 B)$ and telomerase $\left(F_{(2,9)}=9.27 ; p=0.030\right)$ activity alterations (Fig. 1C) and immobility time prolongation $\left(151.2 \pm 8.3\right.$ vs $97.7 \pm 9.7$ s, CMS vs fluoxetine; $F_{(2,30)}=18.83$; $p=0.000 ; n=12)$.

To further investigate whether hippocampal telomerase is implicated in depression-related behaviors, we generated an adeno- 
virus vector that selectively expresses mTERT with a fused green fluorescent protein (GFP) at its $\mathrm{C}$ terminal and named it AdmTERT-GFP. As a control, we also generated an adenovirus vector that expresses GFP alone (Ad-GFP). We infused Ad-mTERT-GFP or Ad-GFP into the bilateral DG of mice by stereotaxic injection. At day 5 after transfection, numerous $\mathrm{GFP}^{+}$cells were observed in the DG, and the mRNA level of mTERT was obviously increased (vs Ad-GFP), indicating a TERT overexpression (Fig. 1D). The mice treated with Ad-mTERT-GFP displayed a significantly decreased immobility time in the TST at day $28\left(F_{(1,21)}=8.83 ; p<0.01\right)$, but not at day 3 after transfection, compared with Ad-GFP (Fig. $1 E$ ). In addition, Ad-mTERT-GFP had no effect on the locomotor activity at both time points (data not shown). Thus, TERT overexpression in the hippocampus produces an antidepressive-like effect in a delayed time manner.

To determine whether hippocampal TERT overexpression affects CMS-induced behavioral modifications, we delivered $2 \mu \mathrm{l}$ of Ad-mTERT-GFP or Ad-GFP by microinjection into the bilateral DG of mice. Four days later, we exposed the mice to CMS for $21 \mathrm{~d}$ and performed behavioral tests the next day. The mice exposed to CMS diminished body weight gain $\left(F_{(2,42)}=72.17 ; p=\right.$ 0.000) (Fig. $1 F$ ), displayed a significantly increased immobility time in the TST $\left(F_{(2,42)}=6.58 ; p=0.013\right)$ (Fig. $\left.1 G\right)$ and forced swimming test $(\mathrm{FST})\left(F_{(2,42)}=7.05 ; p=0.026\right)($ Fig. $1 \mathrm{H})$, and displayed a significantly decreased percentage sucrose preference $\left(F_{(2,42)}=21.29 ; p=0.000\right)$ (Fig. $\left.1 I\right)$ compared with control. Intrahippocampal Ad-mTERT-GFP microinjection prevented the CMS-induced immobility time prolongation in the TST $\left(F_{(2,42)}=6.58 ; p=0.012\right)$ (Fig. $\left.1 G\right)$ and sucrose preference reduction $\left(F_{(2,42)}=21.29 ; p=0.000\right)$ (Fig. $1 I$ ) and ameliorated body weight gain $\left(F_{(2,42)}=72.17 ; p=0.045\right.$ (Fig. $\left.1 F\right)$, indicating that TERT overexpression is protective against the behavioral effects of CMS paradigm.

\section{Inhibiting hippocampal telomerase results in depressive-like phenotype}

To test whether telomerase inhibition produces depressionrelated behavior, we treated mice with AZT (a telomerase inhibitor; 25,50 , or $100 \mathrm{mg} \cdot \mathrm{kg}^{-1} \cdot \mathrm{d}^{-1}$, i.p.) for $14 \mathrm{~d}$. As shown in Figure $2 \mathrm{~A}, \mathrm{AZT}$ inhibited telomerase activities in the hippocampus dose-dependently $\left[75.3 \%\left(F_{(3,8)}=37.48 ; p=0.049\right), 51.6 \%\right.$ $\left(F_{(3,8)}=37.48 ; p=0.001\right)$, and $29.3 \%\left(F_{(3,8)}=37.48 ; p=0.000\right)$ of vehicle for 25,50 , and $100 \mathrm{mg} \cdot \mathrm{kg}^{-1} \cdot \mathrm{d}^{-1}$, respectively]. However, $100 \mathrm{mg} \cdot \mathrm{kg}^{-1} \cdot \mathrm{d}^{-1}$ AZT had no effect on DNA polymerase activity (Fig. $2 B$ ).

Next, we treated mice with AZT $\left(100 \mathrm{mg} \cdot \mathrm{kg}^{-1} \cdot \mathrm{d}^{-1}\right)$ for $14 \mathrm{~d}$ and measured behaviors at day 1, 10, 20, or 30 after withdrawal. The mice treated with AZT displayed a significantly increased immobility time in the TST (at day 20: $F_{(1,18)}=9.74, p<0.01$; at day 30: $F_{(1,18)}=7.96, p<0.01$; Fig. $2 C$ ) and in the FST (at day 10: $F_{(1,18)}=4.81, p<0.05$; at day 20: $F_{(1,18)}=6.93, p<0.05$; at day 30: $F_{(1,18)}=12.48, p<0.01$; Fig. $\left.2 D\right)$ and a significantly decreased percentage sucrose preference (at day 10: $F_{(1,18)}=5.98$, $p<0.05$; at day 20: $F_{(1,18)}=7.67, p<0.01$; at day 30: $F_{(1,18)}=$ $4.55, p<0.05$; Fig. $2 E$ ), compared with vehicle. However, AZT did not change the immobility time in the TST and FST and percentage sucrose preference at $1 \mathrm{~d}$ after withdrawal $(p>0.05)$, and it also did not change immobility time in the TST at $10 \mathrm{~d}$ after withdrawal $\left(F_{(1,18)}=1.85 ; p=0.1786\right)$. In addition, AZT treatment did not influence body weight gain at day 30 after withdrawal [at day 15 after withdrawal: AZT, $3.01 \pm 0.27$ g; vehicle, $3.13 \pm 0.39 \mathrm{~g}(n=10 ; p=0.802)$; at day 30 after withdrawal: AZT, $6.54 \pm 0.34 \mathrm{~g}$; vehicle, $6.71 \pm 0.50 \mathrm{~g}(n=10, p=0.78)]$.
However, the intraperitoneal injection may cause systemic effects. To test whether hippocampal telomerase inhibition results in a depressive-like phenotype, we delivered AZT $(0.7 \mu \mathrm{mol}$, $2 \mu \mathrm{l})$ solution into the bilateral DG of the hippocampus by stereotaxic surgery. Immobility in the TST and FST and sensitivity to reward in the SPT were examined at day 1, 10, 20, or 30 after AZT microinjection. The mice treated with intrahippocampal AZT displayed a significantly increased immobility time in the TST (at day 20: $F_{(1,17)}=9.32, p<0.01$; at day 30: $F_{(1,17)}=5.46$, $p<0.05$; Fig. $2 F$ ) and in the FST (at day 20: $F_{(1,17)}=21.14, p<$ 0.0001; at day 30: $F_{(1,16)}=16.65, p<0.0001$; Fig. $\left.2 G\right)$ and a significantly decreased percentage sucrose preference (at day 20: $F_{(1,16)}=15.90, p<0.001$; at day 30: $F_{(1,16)}=9.61, p<0.01$; Fig. $2 \mathrm{H})$, compared with vehicle. However, AZT did not change immobility time in the TST and FST and percentage sucrose preference either at day 1 or day 10 after treatment $(p>0.05)$ (Fig. $2 \mathrm{~F}-\mathrm{H}$ ).

Additionally, we conducted locomotion studies in the open field test in parallel with the TST and FST studies to identify potentially confounding effects. AZT treatment did not alter locomotor activity of mice at any time point after treatment $(p>$ 0.05) (data not shown). In addition, AZT did not influence the body weight gain of mice at day 30 after AZT microinjection (AZT, $6.39 \pm 0.19 \mathrm{~g}$; vehicle, $6.64 \pm 0.28 \mathrm{~g} ; p>0.4$ ).

\section{Telomerase is critical for the adult neurogenesis}

To determine the effect of hippocampal telomerase inhibition on hippocampal neurogenesis, AZT solution at a dose of $0.175,0.35$, or $0.7 \mu \mathrm{mol}$ was delivered into the left DG of adult male mice by microinjection $(2 \mu \mathrm{l}$ at $0.2 \mu \mathrm{l} / \mathrm{min})$. As a control, $2 \mu \mathrm{l}$ of vehicle was delivered into the right DG. Three hours after microinjection, mice were given injections of the thymidine analog BrdU ( $100 \mathrm{mg} / \mathrm{kg}$, i.p.), a marker of dividing cells, and killed $2 \mathrm{~h}$ later for BrdU staining. The number of $\mathrm{BrdU}^{+}$cells in the DG exposed to $0.175,0.35$, and $0.7 \mu \mathrm{mol}$ of AZT was $1147.2 \pm 42.9$, $1034.7 \pm 95.7$, and $910 \pm 95.8$, respectively. The number of $\mathrm{BrdU}^{+}$cells in the right DG exposed to vehicle was $1577.5 \pm$ $38.3,1584.1 \pm 73.8$, and $1589.7 \pm 187.3$, respectively. Exposure to $0.175,0.35$, and $0.7 \mu \mathrm{mol}$ of AZT decreased the number of $\mathrm{BrdU}^{+}$cells in the DG by $\sim 27.3,34.7$, and $42.8 \%$, respectively, suggesting a dose-dependent cell birth reduction.

Next, we examined the time course of cell birth after intrahippocampal AZT microinjection. We treated mice with BrdU (100 $\mathrm{mg} / \mathrm{kg}$, i.p.) at $3,24,48,72$, or $168 \mathrm{~h}$ after AZT microinjection ( 0.7 $\mu \mathrm{mol})$. Two hours later after BrdU treatment, the mice were killed for BrdU staining. AZT exposure reduced the number of newly generated cells in the DG time-dependently, and the inhibition ratio at $3,24,48,72$, and $168 \mathrm{~h}$ after AZT microinjection was $42.3 \%\left(F_{(1,8)}=15.85 ; p<0.001\right), 40.3 \%\left(F_{(1,8)}=15.29 ; p<\right.$ $0.001), 34.3 \%\left(F_{(1,8)}=10.32 ; p<0.01\right), 31 \%\left(F_{(1,10)}=10.56 ; p<\right.$ $0.01)$, and $18.4 \%\left(F_{(1,10)}=3.67 ; p<0.05\right)$, respectively (Fig. $3 A$, $3 B$ ), suggesting a long-lasting effect of AZT on cell birth. In mammals, adult neurogenesis occurs principally in two neurogenic regions, the SVZ of the lateral ventricle and the subgranular zone of DG (van Praag et al., 2002). AZT delivered into the DG may diffuse into the SVZ and thereby inhibit cell birth in the SVZ. To exclude this possibility, we estimated the number of $\mathrm{BrdU}^{+}$cells in the SVZ at 3, 24, 48, 72, or $168 \mathrm{~h}$ after intrahippocampal AZT microinjection. As shown in Figure $3 C$, intrahippocampal AZT did not change the number of $\mathrm{BrdU}^{+}$cells in the SVZ at any time point $(p>0.05)$.

Finally, we examined whether TERT overexpression promotes hippocampal neurogenesis. We delivered Ad-mTERT- 


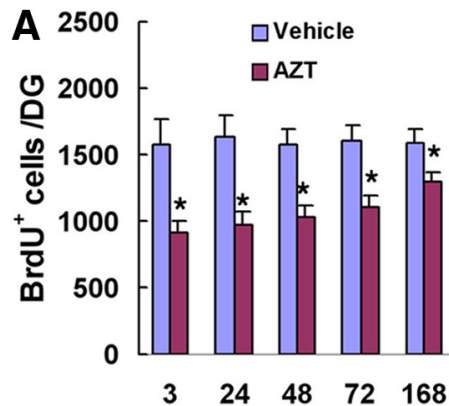

Hours after treatment

D

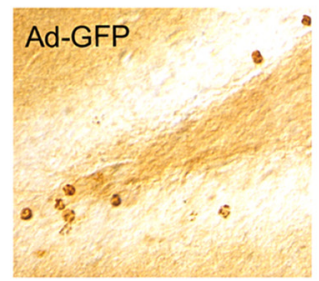

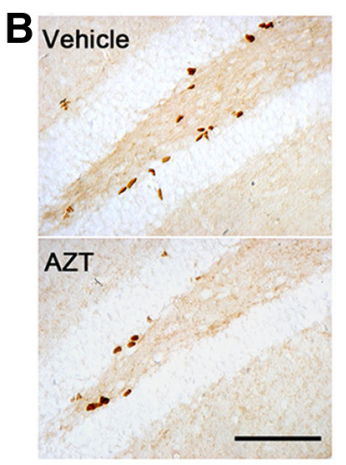

E

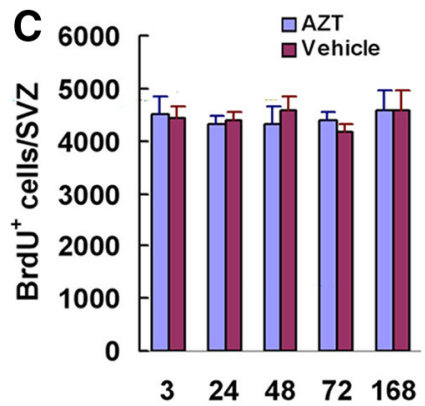

Hours after treatment

Figure 3. Hippocampal telomerase modulates neurogenesis. $A$, Total number of BrdU-positive cells per DG from mice treated with intrahippocampal AZT microinjection (0.7 $\mu$ mol, $2 \mu l$ ) at the time indicated $(n=5-6)$. B, Representative BrdU-positive cells in the DG at $3 \mathrm{~h}$ after AZT microinjection. $\boldsymbol{C}$, Total number of BrdU-positive cells per SVZ from mice treated with intrahippocampal AZT microinjection $(0.7 \mu \mathrm{mol}, 2 \mu \mathrm{l})$ at the time indicated $(n=5-6)$. D, Representative BrdU-positive cells in the DG of mice transfected with Ad-mTERT-GFP or Ad-GFP at $28 \mathrm{~d}$ after BrdU labeling. $\boldsymbol{E}$, Representative BrdU/GFP-positive cells in the DG of mice transfected with Ad-mTERT-GFP at $28 \mathrm{~d}$ after BrdU labeling. Red, BrdU; green, GFP. Arrowheads indicate double-labeled cells. Scale bars: $\boldsymbol{B}$, $200 \mu \mathrm{m} ; \boldsymbol{D}, \boldsymbol{E}, 100 \mu \mathrm{m}$. Data are mean \pm SEM. ${ }^{*} p<0.05$, compared with vehicle.
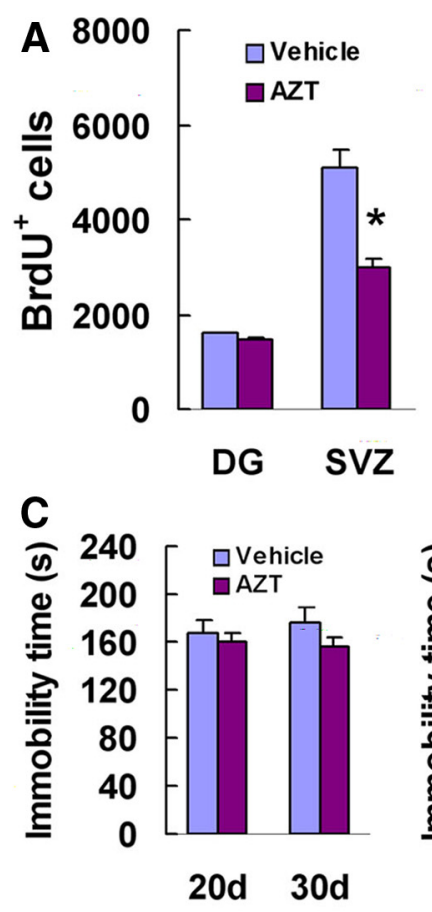

After treatment
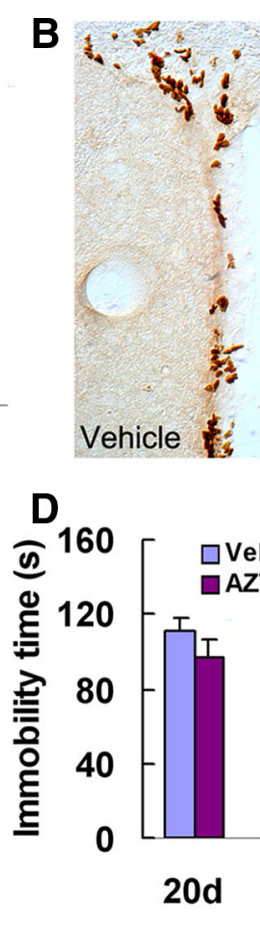

After treatment
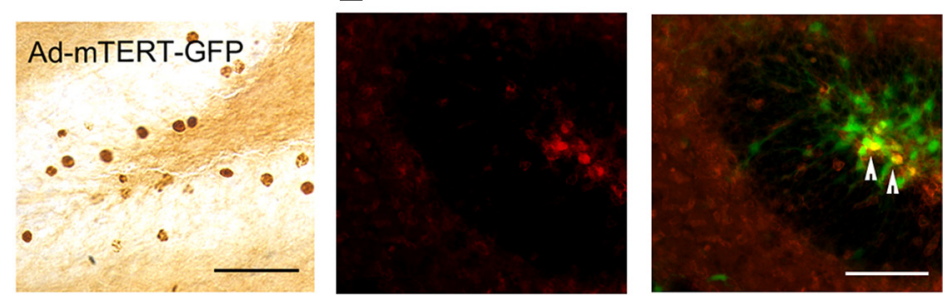
A
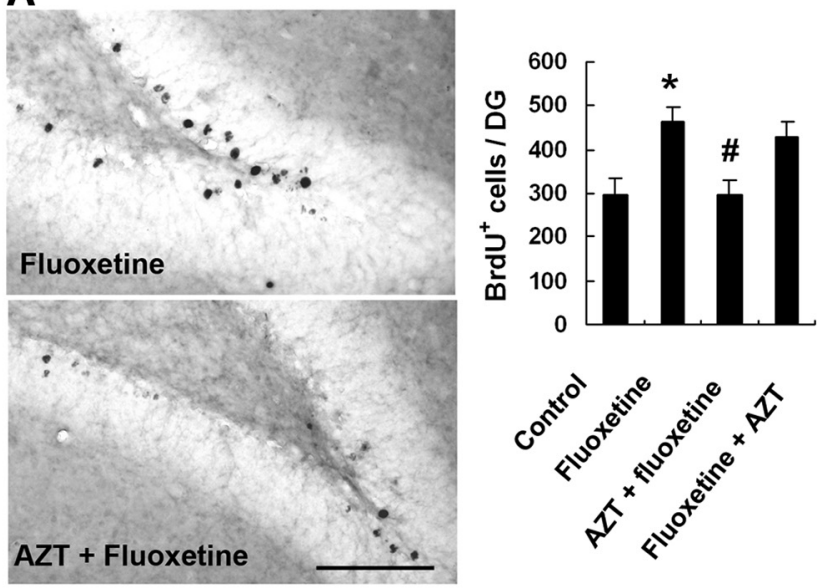

B

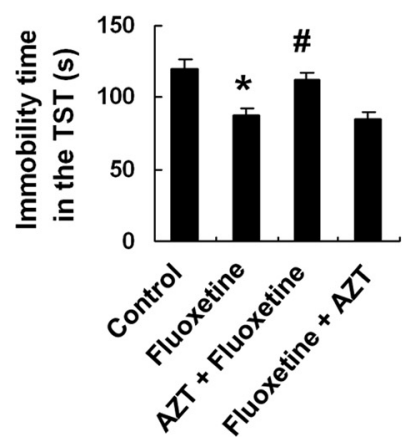

C

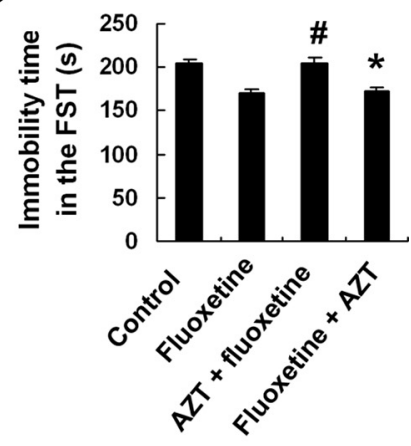

Figure 5. AZT abolishes the neurogenic and behavioral effects of fluoxetine. $\boldsymbol{A}$, Representative BrdU-positive cells (left) and statistical graph showing the number of in the DG of mice (right) after treating with fluoxetine $\left(10 \mathrm{mg} \cdot \mathrm{kg}^{-1} \cdot \mathrm{d}^{-1}\right.$, i.p., for $\left.28 \mathrm{~d}\right)$ with or without AZT (0.7 $\mu \mathrm{mol}, 2 \mu \mathrm{l}$ at $0.2 \mu \mathrm{l} / \mathrm{min}$, intrahippocampal microinjection). Scale bar, $100 \mu \mathrm{m}$. B, C, AZT abolishes behavioral effect of fluoxetine. Shown is the immobility time in the TST ( $\boldsymbol{B}$ ) and FST ( $\boldsymbol{C}$ of the mice after treatment with fluoxetine $\left(10 \mathrm{mg} \cdot \mathrm{kg}^{-1} \cdot \mathrm{d}^{-1}\right.$, i.p., for $28 \mathrm{~d}$ ) with or without AZT (0.7 $\mu \mathrm{mol}, 2 \mu \mathrm{l}$ at $0.2 \mu \mathrm{l} / \mathrm{min}$, intrahippocampal microinjection) $(n=12)$. For the AZT + fluoxetine group, AZT was used at day 0 after starting fluoxetine treatment; for the fluoxetine + AZT group, AZT was used at day 25 after starting fluoxetine treatment. Data are mean \pm SEM. ${ }^{*} p<0.05$, compared with control; ${ }^{*} p<0.05$, compared with fluoxetine.

$2982 \pm 188.6$; vehicle, $\left.5100 \pm 365.8 ; F_{(1,9)}=29.40 ; p=0.0004\right)$ (Fig. $4 A, B)$, but not in the DG (AZT, $1449.6 \pm 76.1$; vehicle, $1599.6 \pm 24.2 ; F_{(1,9)}=3.0 ; p=0.1175$ ) (Fig. $4 A$ ). The AZT microinjection into the SVZ did not alter immobility time in the TST and FST and percentage sucrose preference either at $20 \mathrm{~d}$ or at $30 \mathrm{~d}$ after treatment $(p>0.05)$ (Fig. $4 C-E$ ).

To further determine whether the intrahippocampal AZT injection affects the effects of antidepressants on neurogenesis and behaviors, we treated mice with fluoxetine $\left(10 \mathrm{mg} \cdot \mathrm{kg}^{-1} \cdot \mathrm{d}^{-1}\right.$, i.p.) for $28 \mathrm{~d}$. We delivered $0.7 \mu \mathrm{mol}$ of AZT by microinjection into the bilateral DG $(2 \mu \mathrm{l}$ at $0.2 \mu \mathrm{l} / \mathrm{min})$ at day 0 or day 25 , injected BrdU (100 mg/kg, i.p.) to label newly born cells in the hippocampus at day 1 , and performed behavioral tests and BrdU staining at day 29 after starting fluoxetine treatment. Pretreatment with AZT abolished fluoxetine-induced hippocampal neurogenesis increase $\left(F_{(3,14)}=24.47 ; p=0.000\right)$ (Fig. $5 A$ ) and immobility time decreases in the TST $\left(F_{(3,44)}=10.21 ; p=0.029\right)$ (Fig. $5 B)$ and $\operatorname{FST}\left(F_{(3,44)}=16.82 ; p=0.000\right)$ (Fig. $5 C$ ). However, treatment with AZT at day 25 after fluoxetine treatment had no effect on hippocampal neurogenesis increase $\left(F_{(3,14)}=24.47 ; p=\right.$ 0.829 ) (Fig. $5 A)$ and immobility time in the $\operatorname{TST}\left(F_{(3,44)}=10.21\right.$; $p=0.991)($ Fig. $5 B)$ and FST $\left(F_{(3,44)}=16.82 ; p=0.999\right)$ (Fig.
5C). Thus, telomerase is important for the neurogenic and behavioral effects of antidepressants.

\section{Requirement of neurogenesis for the role of telomerase in behavioral modulation}

A potential concern is that the dose of AZT $(0.7 \mu \mathrm{mol})$ used for intrahippocampal microinjection may cause cell damage. Accordingly, we investigated effects of AZT at a low dose on neurogenesis and behaviors. It is reported that $0.5 \mathrm{~mm}$ AZT inhibited telomerase activity and the growth significantly in the cultured MCF-7 cells (Melana et al., 1998). We thus incubated the cultured adult neural stem cells (NSCs) with $0.5 \mathrm{~mm}$ AZT for $24 \mathrm{~h}$ and examined their telomerase activity and proliferation. AZT $(0.5 \mathrm{~mm})$ significantly inhibited telomerase activity in the NSCs (31.4\% of control; $p=0.000)$, and there was no detectable telomerase activity in the cultured neurons (Fig. $6 \mathrm{~A}$ ). Immunofluorescence tests indicated that many NSCs expressed TERT but not neurons (Fig. $6 \mathrm{~B}$ ). Incubation with $0.5 \mathrm{~mm}$ AZT for $24 \mathrm{~h}$ significantly decreased neurosphere formation compared with control, quantified by cell counting $(0.548 \pm 0.0367$ vs $1.0 \pm 0.432 ; n=3$; $p=0.0013$ ) (Fig. 6C). Similar results were obtained with BrdU incorporation experiments $(10 \mu \mathrm{M}$ BrdU was introduced at $22 \mathrm{~h}$ after AZT exposure) using monolayer-cultured NSCs. The ratio of BrdU-positive cells in AZT-treated NSCs was $37.0 \pm 2.2 \%$, compared with $71.8 \pm 2.6 \%$ in control $(p<0.001)$ (Fig. $6 D)$.

Next, we infused $0.5 \mathrm{~mm}$ AZT solution into the left hippocampus of mice using a $7 \mathrm{~d}$ Alzet osmotic minipump $(6.7 \mu \mathrm{g} / 50 \mu \mathrm{l}$, $0.25 \mu \mathrm{l} / \mathrm{h}$ ), measured telomerase activity, and labeled newly born cells with $\mathrm{BrdU}$ (100 mg/kg, i.p., for proliferation; $200 \mathrm{mg} / \mathrm{kg}$, i.p., for survival) in the hippocampus on the day the minipump was removed. The AZT infusion significantly decreased telomerase activity (14.3 \pm 1.77 vs $36.7 \pm 2.34$ TPG units; $n=3 ; p=0.0016)$ (Fig. $6 E$ ) and newly born cells in the DG (the number of BrdUpositive cells at $2 \mathrm{~h}$ after BrdU labeling; $681.6 \pm 68.5$ vs $1065.6 \pm$ 47.2; $n=5 ; p=0.0017$ ). The AZT infusion also significantly decreased the survival of newly born cells (the number of BrdUpositive cells at $28 \mathrm{~d}$ after BrdU labeling; $377.1 \pm 28.8$ vs $731.8 \pm$ $43.4 ; n=5 ; p<0.001)$. To investigate behavioral modifications, we infused $0.5 \mathrm{~mm}$ AZT solution into the left hippocampus of mice using a $28 \mathrm{~d}$ Alzet osmotic minipump $(26.8 \mu \mathrm{g} / 200 \mu \mathrm{l}, 0.25$ $\mu \mathrm{l} / \mathrm{h}$ ) and performed behavioral tests after the removal of the minipump. The AZT infusion significantly prolonged immobility time in the TST $(142.2 \pm 9.8$ vs $109.5 \pm 9.4 \mathrm{~s} ; n=11-14 ; p=0.018)$ and FST $(197.3 \pm 11.0$ vs $168.6 \pm 5.6 s ; n=11-14 ; p=0.021)$ and decreased percentage sucrose preference (71.2 \pm 4.2 vs $87.4 \pm 1.7 \%$; $n=10-13 ; p=0.0014)$.

As telomere dysfunction can lead to cell death (Hastie et al., 1990; Roy et al., 2004), the behavioral modifications by AZT may be caused by mature neuron and/or newly born cell insults. To exclude this possibility, we incubated the cultured neurons and adult NSCs with $0.5 \mathrm{~mm}$ AZT for $24 \mathrm{~h}$. The AZT incubation did not increase the number of apoptosis cells either in neurons (percentage of PI/Hochest-positive cells, $13.08 \pm 0.76$ vs $13.42 \pm 0.68$; $n=3 ; p=0.809$ ) or in the NSCs (percentage of PI/nestin-positive cells, $25.72 \pm 0.99$ vs $24.97 \pm 0.77 ; n=3 ; p=0.581$ ) (Fig. $7 A$ ). Next, we infused $0.5 \mathrm{~mm}$ AZT solution into the left hippocampus of mice using a $7 \mathrm{~d}$ Alzet osmotic minipump (6.7 $\mu \mathrm{g} / 50 \mu \mathrm{l}, 0.25 \mu \mathrm{l} / \mathrm{h})$. The AZT infusion did not change hippocampal DNA polymerase activity $(p=1.000)$ (Fig. $7 B$ ) and did not cause apoptosis in the hippocampus $(p=0.316)$ (Fig. $7 D)$, although it increased cell proliferation $(p=0.012$ ) (Fig. $7 C)$. Moreover, we delivered 0.7 $\mu \mathrm{mol}$ of AZT ( $2 \mu \mathrm{l}$ at $0.2 \mu \mathrm{l} / \mathrm{min}$ ) into the DG by microinjection. Seven days later, mice were killed to examine cell damage by 

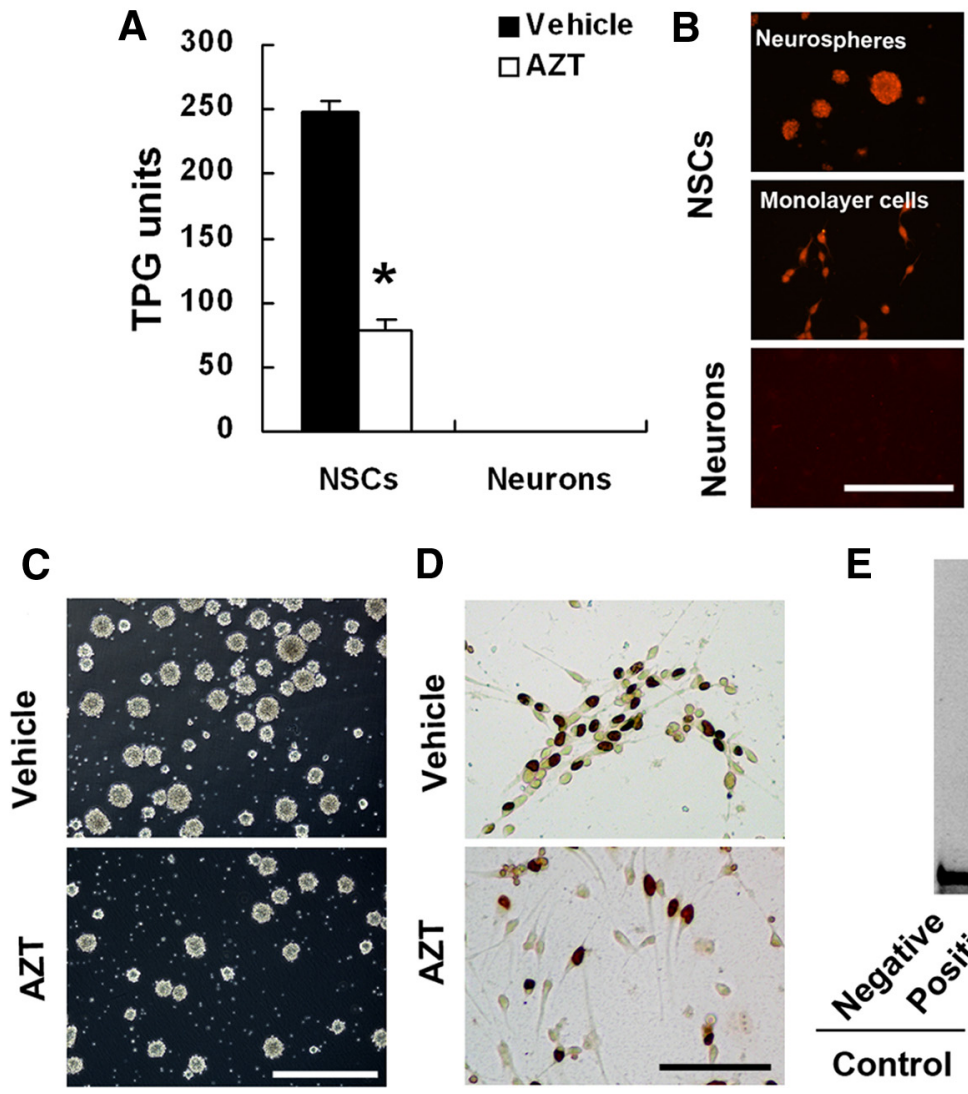

D

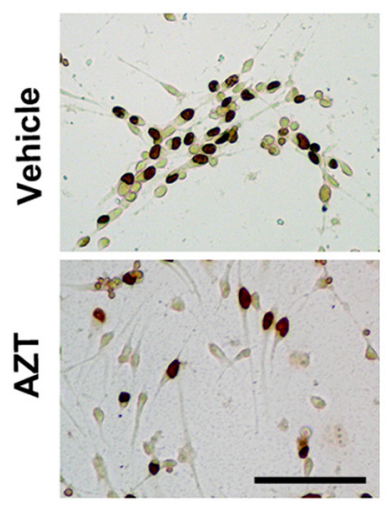

E

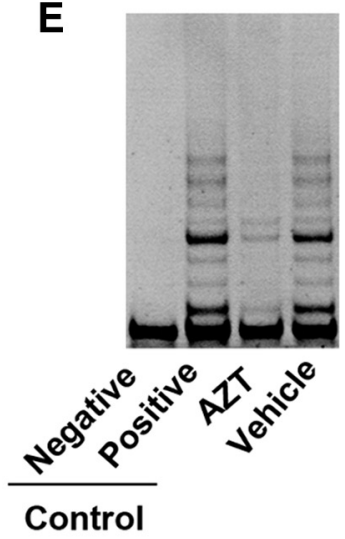

Figure 6. A low dose of AZT inhibits telomerase activity and neurogenesis and produces depressive-like phenotype. $A$, Telomerase activity in the cultured neurons and NSCs incubated with $0.5 \mathrm{~mm}$ AZT for $24 \mathrm{~h}(n=3)$. B, TERT immunofluorescence from the neurosphere-cultured NSCS (top), monolayer-cultured NSCS (middle), and neurons (bottom). C, Representative newly formed neurospheres after treatment with $0.5 \mathrm{~mm}$ AZT or vehicle for $24 \mathrm{~h}$. D, Representative BrdU-labeled cells of the monolayer-cultured NSCs after treatment with $0.5 \mathrm{~mm}$ AZT or vehicle for $24 \mathrm{~h}$. $E$, Representative SYBR Green I-stained gel visualizing TRAP products of sample from the hippocampus of mice treated with intrahippocampal AZT infusion using a $7 \mathrm{~d}$ Alzet osmotic minipump $(6.7 \mu \mathrm{g} / 50$ $\mu \mathrm{l}, 0.25 \mu \mathrm{l} / \mathrm{h})$. Negative control, Taq enzyme-free control; Positive control, cell line expressing high levels of telomerase. Scale bars: $\boldsymbol{B}, \boldsymbol{C}, 400 \mu \mathrm{m} ; \boldsymbol{D}, 100 \mu \mathrm{m}$. Data are mean \pm SEM. ${ }^{*} p<0.05$, compared with vehicle.

staining brain sections with FJ and TUNEL. Neither dead nor apoptotic neurons were observed in the hippocampus of mice treated with AZT (Fig. $7 D, E$ ).

To further determine whether hippocampal neurogenesis accounts for the action of TERT overexpression on behaviors, we sought to disrupt this process by X-irradiation. We delivered 10 or $15 \mathrm{~Gy} x$ ray to the hippocampus of mice, injected BrdU (200 $\mathrm{mg} / \mathrm{kg}$, i.p.) to label newly born cells in the hippocampus at day 12 , and performed behavioral tests at day 36 after the first dose of $\mathrm{x}$ ray. We performed BrdU staining and BrdU/NeuN and BrdU/ GFAP double staining at day 28 after BrdU labeling to test the survival of newborn cells and the percentage of BrdU/NeuN- and BrdU/ GFAP-positive cells. As shown in Figure $8 B, 10$ and 15 Gy x ray resulted in 28.4 and $41.8 \%$ reduction in survival. Compared with the sham-irradiated group, $15 \mathrm{~Gy} x$ ray did not change the percentage of $\mathrm{BrdU} / \mathrm{NeuN}$-positive cells $(84.7 \pm 4.1$ vs $83.3 \pm 1.9 \%$; $p=0.489$; $n=6)$ and BrdU/GFAP-positive cells $(11.1 \pm 2.04$ vs $12.0 \pm$ $0.8 \% ; p=0.349 ; n=6)$. Exposure to $15 \mathrm{~Gy}$ x ray prolonged immobility time in the TST $\left(F_{(2,39)}=3.63 ; p=0.036\right)($ Fig. $8 C)$ and $\operatorname{FST}\left(F_{(2,39)}=5.12 ; p=0.034\right)$ (Fig. $\left.8 D\right)$. Ten Gray x ray prolonged immobility time in the $\operatorname{FST}\left(F_{(2,39)}=5.12 ; p=\right.$ 0.024) (Fig. 8D).

Next, we delivered $2 \mu \mathrm{l}$ off Ad-mTERT-GFP or Ad-GFP into the bilateral DG of mice by stereotaxic microinjection. We delivered 5 Gy x ray three times 32 (total $15 \mathrm{~Gy}$; at days 6, 10, and 14 after transfection, respectively) to the hippocampus of mice treated with AdmTERT-GFP, injected BrdU (100 mg/kg, i.p., for proliferation; $200 \mathrm{mg} / \mathrm{kg}$, i.p., for survival) to label newly born cells in the hippocampus at day 12 , and performed behavioral tests at day 36 after the first dose of $\mathrm{x}$ ray. We performed BrdU staining $2 \mathrm{~h}$ and $28 \mathrm{~d}$ after BrdU labeling to test proliferation and survival, respectively. Ad-mTERT-GFP caused $37.9 \%$ increase in proliferation (Fig. $8 F$ ) and $47.2 \%$ increase in the survival of newly born cells (Fig. 8G). The X-irradiation abolished the effects of Ad-mTERT-GFP not only on proliferation $\left(F_{(2,33)}=72.53 ; p=0.000\right)$ (Fig. $8 F)$ and survival $\left(F_{(2,29)}=56.89 ; p=\right.$ 0.000 ) (Fig. $8 G$ ) but also on the latency in the $\operatorname{TST}\left(F_{(2,49)}=5.32 ; p=0.028\right)$ (Fig. $8 H)$ and FST $\left(F_{(2,29)}=5.54 ; p=0.036\right)$ (Fig. 8I). These results suggest that hippocampal neurogenesis contributes to the role of telomerase in behavioral modulation.

\section{Discussion}

Here, we report that chronic stress results in telomerase reduction in the adult hippocampus. Inhibiting hippocampal telomerase decreases neurogenesis, induces depression-like phenotype, and abolishes the behavioral effects of an antidepressant. In contrast, overexpression of TERT in the hippocampus stimulates neurogenesis, produces an antidepressive-like effect, and prevents the CMS-induced behavioral modifications. Moreover, disrupting hippocampal neurogenesis blocks behavioral responses to TERT

overexpression.

Stressful stimuli have a substantial causal association with depression, and stress paradigms have long been used to model the disease (Martinowich et al., 2007; Zhou et al., 2007; Bartolomucci and Leopardi, 2009). We show here that chronic stress led to hippocampal telomerase expression and activity reductions. Consistently, it has been demonstrated that psychological stress, including perceived stress and chronicity of stress, is significantly associated with lower telomerase activity and shorter telomere length in peripheral blood mononuclear cells (Epel et al., 2004). Recently, it was reported that major depressive disorder has a statistically significant shortening effect on telomeric length (Lung et al., 2007). We used AZT to inhibit telomerase activity and found that both systemic and hippocampal telomerase inhibition caused a depressive-like phenotype and abolished the behavioral effects of fluoxetine in mice. More importantly, overexpression of TERT in the hippocampus produced an antidepressive-like effect. Thus, hippocampal telomerase is significantly implicated in the regulation of depressive behaviors.

Perturbations in adult hippocampal neurogenesis are believed to be relevant to various physiological and pathological processes such as learning and memory, epilepsy, schizophrenia, stroke, etc. (Gould et al., 1999; Zhu et al., 2003, 2004; DeCarolis and Eisch, 2010). Multiple studies have shown that antidepressants 
enhance hippocampal neurogenesis (Jacobs et al., 2000; Malberg, 2004; Chen et al., 2006) and that hippocampal neurogenesis is required for their behavioral effects (Santarelli et al., 2003). Although it is not well known whether decreased neurogenesis can induce a depressive-like effect (Sapolsky, 2004), our findings that telomerase overexpression produced an antidepressive-like effect, increased neurogenesis, and prevented the CMSinduced behavioral modifications suggest a possibility that telomerase may modify depressive behaviors via promoting neurogenesis. Additional support for this hypothesis comes from that disrupting hippocampal neurogenesis by AZT or $\mathrm{X}$-irradiation produced depressive-like behaviors and X-irradiation abolished behavioral effects of TERT overexpression. Especially, intrahippocampal single AZT microinjection or AZT infusion using a minipump caused $\sim 40 \%$ reduction in local cell proliferation and produced an extremely significant depressive-like effect, suggesting important significance of neurogenesis for behavioral phenotype. As the microinjection of AZT into the SVZ impaired local cell birth without affecting behaviors, hippocampal but not SVZ neurogenesis is critical for the effect of telomerase on behaviors.

Interestingly, our findings that $\mathrm{X}$ irradiation of a restricted region of mouse brain containing the hippocampus or intrahippocampal AZT microinjection blocked neurogenesis in the DG and produced depression-like behaviors in the TST and FST suggest that impaired hippocampal neurogenesis may constitute cellular mechanisms of depressive behaviors. However, an inconsistency with our current results is that ablation of hippocampal neurogenesis via irradiation does not elicit a behavioral modification in the novelty suppressed feeding (NSF) test (Santarelli et al., 2003;

Surget et al., 2008; David et al., 2009; Zhu et al., 2010). The NSF test and the TST or FST test characterize different behaviors. The NSF procedure is a conflict test that elicits competing motivations: the drive to eat and the fear of venturing into the center of a brightly lit arena (Bodnoff et al., 1988). The latency to feed in the NSF test has been used as an index of anxiety-like behaviors (Santarelli et al., 2003). The FST and the TST have been developed to evaluate depression-like behaviors in mice (Porsolt et al., 1977; Steru et al., 1985). The immobility of the animal in FST and TST reflects a state of "behavioral despair." It has been reported that C57BL/6Ntac and CD1 mice treated with a low dose of corticosterone (35 $\mu \mathrm{g} \cdot \mathrm{ml}^{-1} \cdot \mathrm{d}^{-1}$ or $5 \mathrm{mg} \cdot \mathrm{kg}^{-1} \cdot \mathrm{d}^{-1}$ ) for 4 weeks developed an anxiety-like phenotype in both the open field and the NSF test but displayed a normal behavior in the FST test (David et al., 2009). Thus, the inconsistency between our findings and these reports (Santarelli et al., 2003; Surget et al., 2008; David et al., 2009; Zhu et al., 2010) raises a possibility that impaired hippocampal neurogenesis pus of mice treated with in
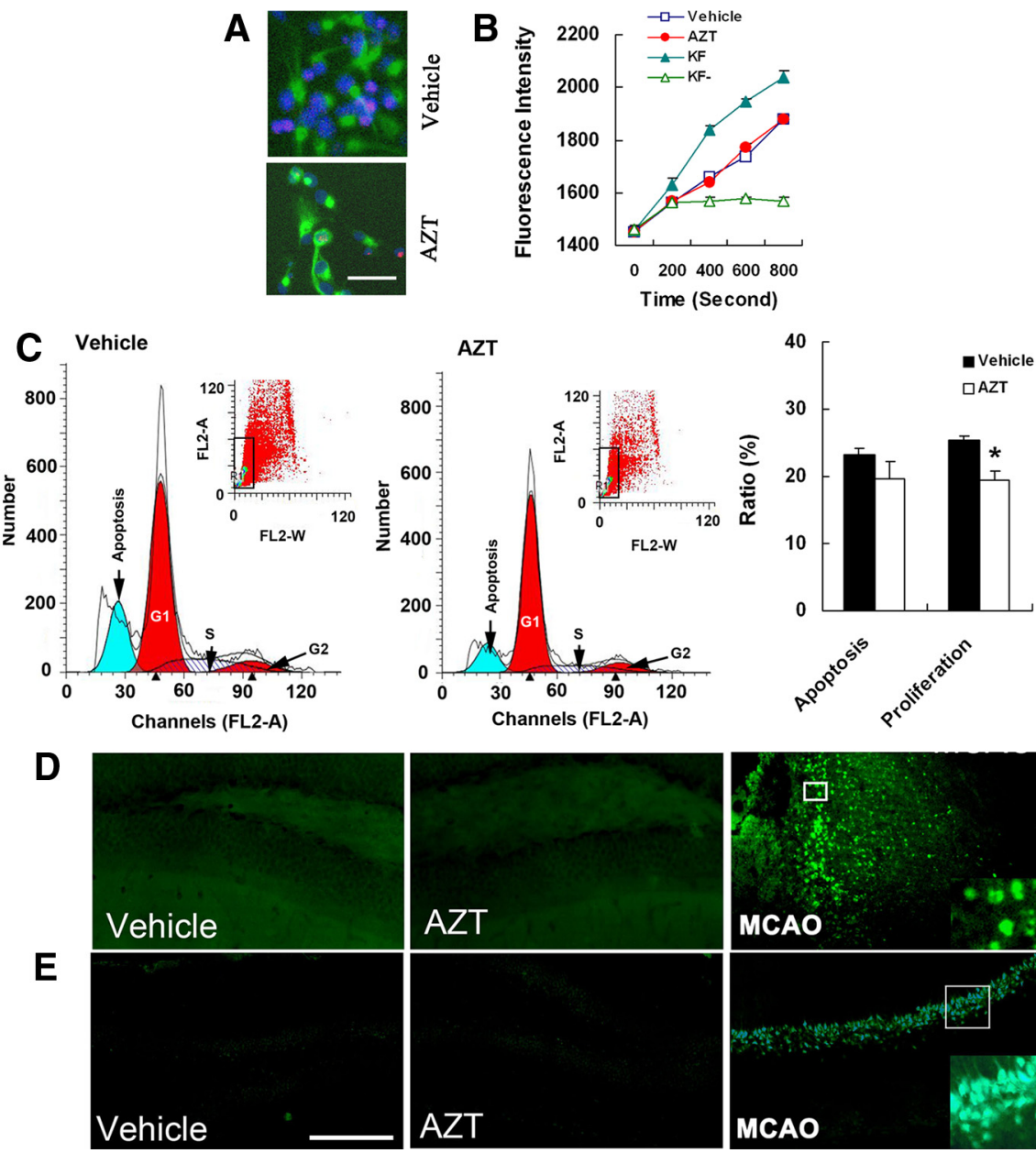

Figure 7. AZT does not cause cells damage. $\boldsymbol{A}$, Representative PI-positive cells in the cultured NSCs (labeled by nestin) incubated DNA pos activity in the hippocampus of mice treated with intrahippocampal AZT infusion using a $7 \mathrm{~d}$ Alzet osmotic Cell cycle analysis was performed using PI staining by flow cytometry. D, Representative DG stained with TUNEL from vehicleHigher magnification shows TUNEL ${ }^{+}(\boldsymbol{D})$ or FJ-stained $(\boldsymbol{E})$ cells in the selected area. Scale bars: $\boldsymbol{B}, 30 \mu \mathrm{m} ; \boldsymbol{D}, \boldsymbol{E}, 200 \mu \mathrm{m}$. Data are mean \pm SEM. ${ }^{*} p<0.05$, compared with vehicle.

may give rise to a certain type of behavioral modification. There are reports that ablation of hippocampal neurogenesis via X-irradiation had no significant effect on immobility in the FST test (Airan et al., 2007; David et al., 2009) and another report that decreasing neurogenesis in the receptor tyrosine kinase TrkB conditional knock-out mice carrying the hGFAP-Cre (TrkB ${ }^{\text {hGFAP }}$ ) did not change immobility time in the TST (Li et al., 2008). In the research by Airan et al. (2007), a smaller sample size $(n=6)$ may be the cause of the statistical insignificance. In the report by David et al. (2009), they treated animals with $\mathrm{X}$-irradiation in combination with a long-term corticosterone $\left(35 \mu \mathrm{g} \cdot \mathrm{ml}^{-1} \cdot \mathrm{d}^{-1}\right.$ or $\left.5 \mathrm{mg} \cdot \mathrm{kg}^{-1} \cdot \mathrm{d}^{-1}\right)$. The combination treatment may complicate results. In the study by $\mathrm{Li}$ et al. (2008), the abnormal behavioral phenotype in TrkB KO mice may mask some behavioral modifications, as TrkB ablation renders mice behaviorally insensitive to antidepressive treatment.

The effects of AZT on cell proliferation happen very quickly. It is hard to envisage how such effects can be related to telomere 

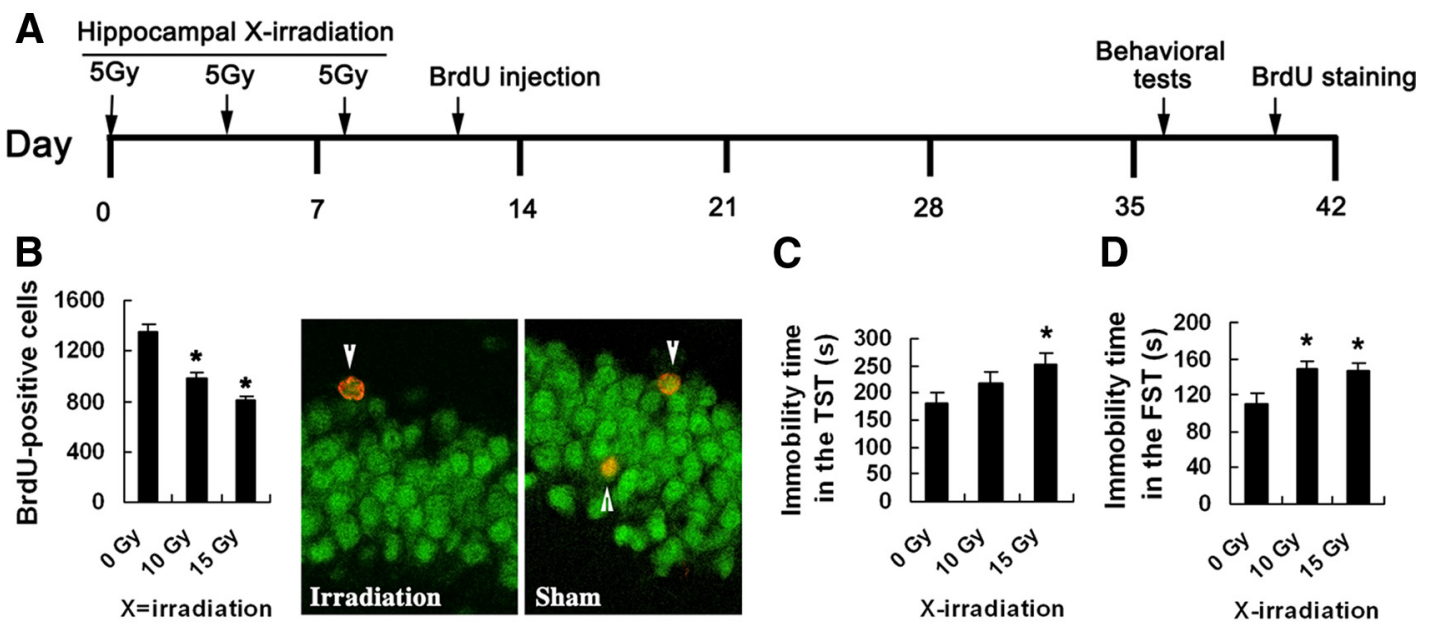

E

Hippocampal X-irradiation
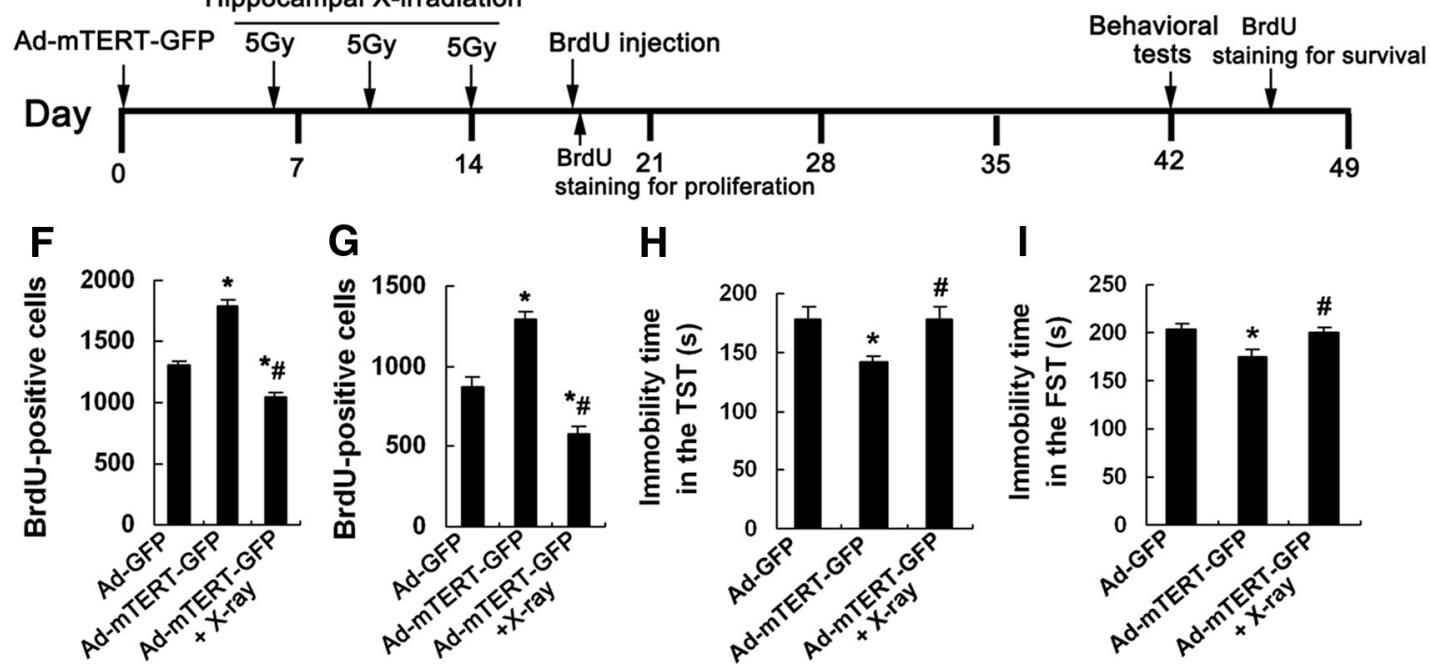

Figure 8. Hippocampal neurogenesis is required for Ad-mTERT-GFP-induced antidepressant-like effect. $\boldsymbol{A}$, Schematic representation of experimental design for $\boldsymbol{B}-\boldsymbol{D}$. $\boldsymbol{B}$, Number of BrdU-labeled cells in the DG of mice exposed to 0, 10, or 15 Gy X-irradiation ( $n=10$ ) (left) and representative BrdU/NeuN-positive cells in the DG of mice exposed to 15 Gy X-irradiation (right). Green, NeuN; red, BrdU. Arrowheads indicate the double-labeled cells. C, Immobility time of mice exposed to 0, 10, or $15 \mathrm{~Gy}$ X-irradiation in the TST test $(n=13-15)$. D, Immobility time of mice exposed to 0 , 10, or 15 Gy X-irradiation in the FST test $(n=13-15)$. $\boldsymbol{E}$, Schematic representation of experimental design for $\boldsymbol{F}$ - $\boldsymbol{I}$. $\boldsymbol{F}$, Number of BrdU-positive cells $2 \mathrm{~h}$ after BrdU labeling in the DG of mice with Ad-mTERT-GFP transfection and exposed to 15 Gy X-irradiation ( $n=10-14)$. G, Number of BrdU-positive cells $28 \mathrm{~d}$ after BrdU labeling in the DG of mice with Ad-mTERT-GFP transfection and exposed to 15 Gy X-irradiation $(n=10-12)$. $\boldsymbol{H}$, Immobility time of mice with Ad-mTERT-GFP transfection and exposed to 15 Gy X-irradiation in the TST test $(n=13-16)$. I, Immobility time of mice with Ad-mTERT-GFP transfection and exposed to $15 \mathrm{~Gy} X$-irradiation in the FST test $(n=13-16)$. Data are mean \pm SEM. ${ }^{*} p<0.05$, compared with 0 Gy X-irradiation $(\boldsymbol{B}-\boldsymbol{D})$ or with Ad-GFP $(\boldsymbol{F}-\boldsymbol{I})$; $\# p<0.05$, compared with Ad-mTERT-GFP.

length, which changes very slowly with successive cell divisions. Although TERC and TERT function together to elongate telomeres and to protect chromosomal ends (Calado and Chen, 2006), TERT is constitutively expressed in the hippocampus, but TERC was not detected in hippocampus (Lee et al., 2010). In fact, overexpression of TERT promotes stem cell proliferation without changes in length of telomeres (Calado and Chen, 2006). Thus, the telomerase functional characteristic in the hippocampus is TERC independent and is operated through a mechanism other than telomere elongation.

Mice with Ad-mTERT-GFP transfection subjected to Xirradiation exhibited immobility times similar to sham-irradiated Ad-GFP and above sham Ad-mTERT-GFP mice in the TST and FST. However, since a reduction of neurogenesis by X-irradiation in control animals increased immobility time in the TST and FST, factors other than modulation of adult neurogenesis may contribute to the behavioral effects of TERT overexpression. Indeed, several reports indicate the significance of telomerase in protecting neuronal death in vitro and in vivo (Martín-Rivera et al., 1998; Klapper et al., 2001; Kang et al., 2004). TERT overexpression decreased apoptosis in PC12 cells induced by trophic factor withdrawal (Fu et al., 2000) and resulted in apparent resistance to cerebral ischemic injury and NMDA receptor-mediated neurotoxicity in the mouse brain (Kang et al., 2004). TERT downregulation increased the sensitivity of hippocampal neurons to excitotoxicity (Fu et al., 2000), and TERT-deficient neurons were more sensitive to NMDA than wild-type ones (Lee et al., 2008). Moreover, intrahippocampal AZT infusion caused $36.1 \%$ reduction in proliferation and $48.6 \%$ reduction in survival. Hippocampal Ad-mTERT-GFP transfection caused 37.9\% increase in proliferation and $47.2 \%$ increase in the survival of newly born cells. These results suggest that telomerase not only plays an important role in proliferation of NSCs but also benefits the survival of newly born cells.

Together, the results of the present study indicate that hippocampal telomerase may be involved in the molecular mecha- 
nism for regulation of the depressive behaviors, providing new insight into the neurobiology of depression.

\section{References}

Airan RD, Meltzer LA, Roy M, Gong Y, Chen H, Deisseroth K (2007) Highspeed imaging reveals neurophysiological links to behavior in an animal model of depression. Science 317:819-823.

Bartolomucci A, Leopardi R (2009) Stress and depression: preclinical research and clinical implications. PLoS One 4:4265.

Blackburn EH (2001) Switching and signaling at the telomere. Cell 106:661-673.

Bodnoff SR, Suranyi-Cadotte B, Aitken DH, Quirion R, Meaney MJ (1988) The effects of chronic antidepressant treatment in an animal model of anxiety. Psychopharmacology 95:298-302.

Cai J, Wu Y, Mirua T, Pierce JL, Lucero MT, Albertine KH, Spangrude GJ, Rao MS (2002) Properties of a fetal multipotent neural stem cell (NEP cell). Dev Biol 251:221-240.

Calado RT, Chen J (2006) Telomerase: not just for the elongation of telomeres. Bioessays 28:109-112.

Caporaso GL, Lim DA, Alvarez-Buylla A, Chao MV (2003) Telomerase activity in the subventricular zone of adult mice. Mol Cell Neurosci 23:693-702.

Chen H, Pandey GN, Dwivedi Y (2006) Hippocampal cell proliferation regulation by repeated stress and antidepressants. Neuroreport 17:863-867.

Czeh B, Michaelis T, Watanabe T, Frahm J, de Biurrun G, van Kampen M, Bartolomucci A, Fuchs E (2001) Stress-induced changes in cerebral metabolites, hippocampal volume, and cell proliferation are prevented by antidepressant treatment with tianeptine. Proc Natl Acad Sci U S A 98:12796-12801.

David DJ, Samuels BA, Rainer Q, Wang JW, Marsteller D, Mendez I, Drew M, Craig DA, Guiard BP, Guilloux JP, Artymyshyn RP, Gardier AM, Gerald C, Antonijevic IA, Leonardo ED, Hen R (2009) Neurogenesisdependent and -independent effects of fluoxetine in an animal model of anxiety/depression. Neuron 62:479-493.

DeCarolis NA, Eisch AJ (2010) Hippocampal neurogenesis as a target for the treatment of mental illness: a critical evaluation. Neuropharmacology 58:884-893.

Dranovsky A, Hen R (2006) Hippocampal neurogenesis: regulation by stress and antidepressants. Biol Psychiatry 59:1136-1143.

Ducottet C, Griebel G, Belzung C (2003) Effects of the selective nonpeptide corticotropin-releasing factor receptor 1 antagonist antalarmin in the chronic mild stress model of depression in mice. Prog Neuropsychopharmacol Biol Psychiatry 27:625-631.

Epel ES, Blackburn EH, Lin J, Dhabhar FS, Adler NE, Morrow JD, Cawthon RM (2004) Accelerated telomere shortening in response to life stress. Proc Natl Acad Sci U S A 101:17312-17315.

Feng J, Funk WD, Wang SS, Weinrich SL, Avilion AA, Chiu CP, Adams RR, Chang E, Allsopp RC, Yu J (1995) The RNA component of human telomerase. Science 269:1236-1241.

Flores I, Benetti R, Blasco MA (2006) Telomerase regulation and stem cell behaviour. Curr Opin Cell Biol 18:254-260.

Flores I, Canela A, Vera E, Tejera A, Cotsarelis G, Blasco MA (2008) The longest telomeres: a general signature of adult stem cell compartments. Genes Dev 22:654-667.

Fu W, Killen M, Culmsee C, Dhar S, Pandita TK, Mattson MP (2000) The catalytic subunit of telomerase is expressed in developing brain neurons and serves a cell survival-promoting function. J Mol Neurosci 14:3-15.

Gould E, Beylin A, Tanapat P, Reeves A, Shors TJ (1999) Learning enhances adult neurogenesis in the hippocampal formation. Nat Neurosci 2:260-265.

Grippo AJ, Sullivan NR, Damjanoska KJ, Crane JW, Carrasco GA, Shi J, Chen Z, Garcia F, Muma NA, Van de Kar LD (2005) Chronic mild stress induces behavioral and physiological changes, and may alter serotonin $1 \mathrm{~A}$ receptor function, in male and cycling female rats. Psychopharmacology 179:769-780.

Hastie ND, Dempster M, Dunlop MG, Thompson AM, Green DK, Allshire RC (1990) Telomere reduction in human colorectal carcinoma and with ageing. Nature 346:866-868.

Jacobs BL, van Praag H, Gage FH (2000) Adult brain neurogenesis and psychiatry: a novel theory of depression. Mol Psychiatry 5:262-269.

Jhaveri DJ, Mackay EW, Hamlin AS, Marathe SV, Nandam LS, Vaidya VA,
Bartlett PF (2010) Norepinephrine directly activates adult hippocampal precursors via beta3-adrenergic receptors. J Neurosci 30:2795-2806.

Kang HJ, Choi YS, Hong SB, Kim KW, Woo RS, Won SJ, Kim EJ, Jeon HK, Jo SY, Kim TK, Bachoo R, Reynolds IJ, Gwag BJ, Lee HW (2004) Ectopic expression of the catalytic subunit of telomerase protects against brain injury resulting from ischemia and NMDA-induced neurotoxicity. J Neurosci 24:1280-1287.

Kao HT, Cawthon RM, DeLisi LE, Bertisch HC, Ji F, Gordon D, Benedict MM, Greenberg WM, Porton B (2008) Rapid telomere erosion in schizophrenia. Mol Psychiatry 13:118-119.

Kim NW, Piatyszek MA, Prowse KR, Harley CB, West MD, Ho PL, Coviello GM, Wright WE, Weinrich SL, Shay JW (1994) Specific association of human telomerase activity with immortal cells and cancer. Science 266:2011-2015.

Klapper W, Shin T, Mattson MP (2001) Differential regulation of telomerase activity and TERT expression during brain development in mice. J Neurosci Res 64:252-260.

Kodama M, Fujioka T, Duman RS (2004) Chronic olanzapine or fluoxetine administration increases cell proliferation in hippocampus and prefrontal cortex of adult rat. Biol Psychiatry 56:570-580.

Lee J, Sung YH, Cheong C, Choi YS, Jeon HK, Sun W, Hahn WC, Ishikawa F, Lee HW (2008) TERT promotes cellular and organismal survival independently of telomerase activity. Oncogene 27:3754-3760.

Lee J, Jo YS, Sung YH, Hwang IK, Kim H, Kim SY, Yi SS, Choi JS, Sun W, Seong JK, Lee HW (2010) Telomerase deficiency affects normal brain functions in mice. Neurochem Res 35:211-218.

Li Y, Luikart BW, Birnbaum S, Chen J, Kwon CH, Kernie SG, Bassel-Duby R, Parada LF (2008) TrkB regulates hippocampal neurogenesis and governs sensitivity to antidepressive treatment. Neuron 59:399-412.

Lung FW, Chen NC, Shu BC (2007) Genetic pathway of major depressive disorder in shortening telomeric length. Psychiatric Genet 17:195-199.

Luo CX, Jin X, Cao CC, Zhu MM, Wang B, Chang L, Zhou QG, Wu HY, Zhu DY (2010) Bidirectional regulation of neurogenesis by neuronal nitric oxide synthase derived from neurons and neural stem cells. Stem Cells 28:2041-2052.

Malberg JE (2004) Implications of adult hippocampal neurogenesis in antidepressant action. J Psychiatry Neurosci 29:196-205.

Martinowich K, Manji H, Lu B (2007) New insights into BDNF function in depression and anxiety. Nat Neurosci 10:1089-1093.

Martín-Rivera L, Herrera E, Albar JP, Blasco MA (1998) Expression of mouse telomerase catalytic subunit in embryos and adult tissues. Proc Natl Acad Sci U S A 95:10471-10476.

Melana SM, Holland JF, Pogo BGT (1998) Inhibition of cell growth and telomerase activity of breast cancer cells in vitro by $3^{\prime}$-azido-3'-deoxythymidine. Clin Cancer Res 4:693-696.

Munoz JR, Stoutenger BR, Robinson AP, Spees JL, Prockop DJ (2005) Human stem progenitor cells from bone marrow promote neurogenesis of endogenous neural stem cells in the hippocampus of mice. Proc Natl Acad Sci U S A 102:18171-18176.

Perera TD, Coplan JD, Lisanby SH, Lipira CM, Arif M, Carpio C, Spitzer G, Santarelli L, Scharf B, Hen R, Rosoklija G, Sackeim HA, Dwork AJ (2007) Antidepressant-induced neurogenesis in the hippocampus of adult nonhuman primates. J Neurosci 27:4894-4901.

Porsolt RD, Bertin A, Jalfre M (1977) Behavioral despair in mice: primary screening test for antidepressants. Arch Int Pharmacodyn Ther 229:327-336.

Porton B, Delisi LE, Bertisch HC, Ji F, Gordon D, Li P, Benedict MM, Greenberg WM, Kao HT (2008) Telomerase levels in schizophrenia: a preliminary study. Schizophr Res 106:242-247.

Roy NS, Nakano T, Keyoung HM, Windrem M, Rashbaum WK, Alonso ML, Kang J, Peng W, Carpenter MK, Lin J, Nedergaard M, Goldman SA (2004) Telomerase immortalization of neuronally restricted progenitor cells derived from the human fetal spinal cord. Nat Biotechnol 22:297-305

Sahay A, Hen R (2007) Adult hippocampal neurogenesis in depression. Nat Neurosci 10:1110-1115.

Santarelli L, Saxe M, Gross C, Surget A, Battaglia F, Dulawa S, Weisstaub N, Lee J, Duman R, Arancio O, Belzung C, Hen R (2003) Requirement of hippocampal neurogenesis for the behavioral effects of antidepressants. Science 301:805-809.

Sapolsky RM (2004) Is impaired neurogenesis relevant to the affective symptoms of depression? Biol Psychiatry 56:137-139. 
Schwob AE, Nguyen LJ, Meiri KF (2008) Immortalization of neural precursors when telomerase is overexpressed in embryonal carcinomas and stem cells. Mol Biol Cell 19:1548-1560.

Simon NM, Smoller JW, McNamara KL, Maser RS, Zalta AK, Pollack MH, Nierenberg AA, Fava M, Wong KK (2006) Telomere shortening and mood disorders: preliminary support for a chronic stress model of accelerated aging. Biol Psychiatry 60:432-435.

Steru L, Chermat R, Thierry B, Simon P (1985) The tail suspension test: a new method for screening antidepressants in mice. Psychopharmacology $85: 367-370$

Surget A, Saxe M, Leman S, Ibarguen-Vargas Y, Chalon S, Griebel G, Hen R, Belzung C (2008) Drug-dependent requirement of hippocampal neurogenesis in a model of depression and of antidepressant reversal. Biol Psychiatry 64:293-301.

Tang Z, Wang K, Tan W, Li J, Liu L, Guo Q, Meng X, Ma C, Huang S (2003) Real-time monitoring of nucleic acid ligation in homogenous solutions using molecular beacons. Nucleic Acids Res 31:e148.

Tsankova NM, Berton O, Renthal W, Kumar A, Neve RL, Nestler EJ (2006) Sustained hippocampal chromatin regulation in a mouse model of depression and antidepressant action. Nat Neurosci 9:519-525.

van Praag H, Schinder AF, Christie BR, Toni N, Palmer TD, Gage FH (2002) Functional neurogenesis in the adult hippocampus. Nature 415:10301034.

Warner-Schmidt JL, Duman RS (2006) Hippocampal neurogenesis: oppos- ing effects of stress and antidepressant treatment. Hippocampus 16: 239-249.

Willner P (1997) Validity, reliability and utility of the chronic mild stress model of depression: a 10-year review and evaluation. Psychopharmacology 134:319-329.

Yoon SO, Lois C, Alvirez M, Alvarez-Buylla A, Falck-Pedersen E, Chao MV (1996) Adenovirus-mediated gene delivery into neuronal precursors of the adult mouse brain. Proc Natl Acad Sci U S A 93:11974-11979.

Zhou QG, Hu Y, Hua Y, Hu M, Luo CX, Han X, Zhu XJ, Wang B, Xu JS, Zhu DY (2007) Neuronal nitric oxide synthase contributes to chronic stressinduced depression by suppressing hippocampal neurogenesis. J Neurochem 103:1843-1854.

Zhu DY, Liu SH, Sun SH, Lu YM (2003) Expression of inducible nitric oxide synthase after focal cerebral ischemia stimulates neurogenesis in the adult animal dentate gyrus. J Neurosci 23:223-229.

Zhu DY, Lau L, Wei JS, Liu SH, Lu YM (2004) Activation of cAMPresponse-element-binding protein (CREB) after focal cerebral ischemia stimulates neurogenesis in the adult dentate gyrus. Proc Natl Acad Sci U S A 101:9453-9457.

Zhu XH, Yan HC, Zhang J, Qu HD, Qiu XS, Chen L, Li SJ, Cao X, Bean JC, Chen LH, Qin XH, Liu JH, Bai XC, Mei L, Gao TM (2010) Intermittent hypoxia promotes hippocampal neurogenesis and produces antidepressant-like effects in adult rats. J Neurosci 30:12653-12663. 